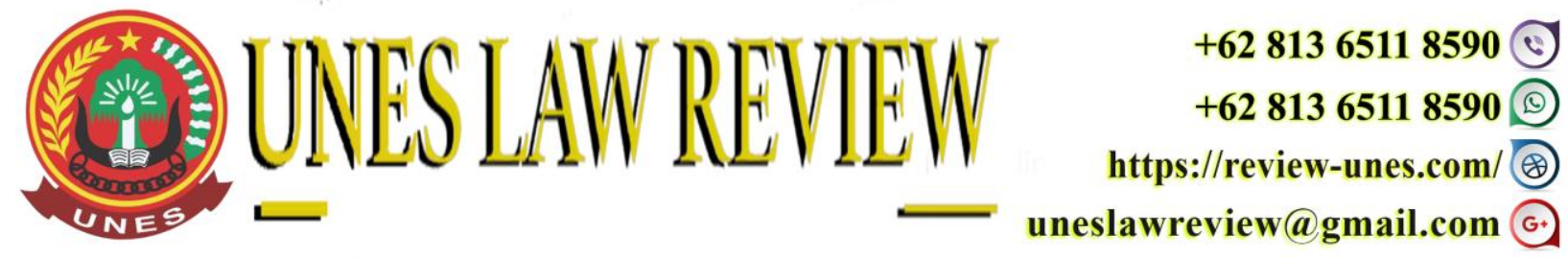

DOI: https://doi.org/10.31933/unesrev.v4i2

Diterima: 02/11/2021, Diperbaiki: 29/11/2021, Diterbitkan: 24/12/2021

\title{
HAK AHLI WARIS PEKERJA MENINGGAL DUNIA DALAM HUKUM KETENAGAKERJAAN DI INDONESIA (ANALISIS PUTUSAN PHI PADA PN SURABAYA NOMOR 74/G/2014/PHI.SBY JO. PUTUSAN MA RI NO. 225 K/PDT.SUS PHI/2015)
}

\author{
${ }^{1}$ Neni Vesna Madjid, ${ }^{2}$ Afrinal \\ ${ }^{1}$ Magister Ilmu Hukum, Fakultas Hukum, Universitas Ekasakti, Padang, Indonesia. \\ Email:nenivesna@gmail.com \\ ${ }^{2}$ Fakultas Syari'ah UIN Imam Bonjol, Padang, Indonesia. \\ Email: afrinalnal67@gmail.com
}

Corresponding Author: Neni Vesna Madjid

\section{ABSTRACT}

The death of the worker will also end the employment relationship with himself or known as Termination of Employment for the sake of law. As a consequence of the death of the worker, there are heirs who are accepted. In this paper, the author discusses the inheritance rights of workers who die starting from the provisions in Article $1603 \mathrm{j}$ of the Civil Code and the provisions of Article 1601 y of the Civil Code. Further, the provisions of Article 61 of Law no. 13 of 2003 concerning Manpower as well as in the provisions of Law no. 166 Law no. 13 of 2003 concerning Manpower. However, the birth of Law no. 11 of 2020 concerning Job Creation, abolishing the provisions of Article 166 of Law no. 13 of 2003 concerning Manpower, and contains the substance of Article 166 of Law no. 13 of 2003, in the provisions of Article 57 of Government Regulation of the Republic of Indonesia (PP) Number 35 of 2021 concerning Work Agreements for Certain Time, Outsourcing, Working Time and Rest Time, and Termination of Employment which are implementing regulations of the Ciptaker Law. The author also conducted an analysis of the application of the rights of heirs who died based on the PHI decision at the Surabaya District Court No. 74/G/2014/PHI.Sby jo. RI Supreme Court Decision No. 225 K/Pdt.Sus PHI/2015)

Keywords: Rights of Heirs, Employees, Employment Law 


\begin{abstract}
ABSTRAK
Meninggalnya pekerja maka berakhir pula hubungan kerja dengan sendiri atau dikenal dengan Pemutusan Hubungan Kerja demi hukum. Konsekwensi dari meninggalnya pekerja, ada hak ahli waris yang diterima. Dalam tulisan ini penulis membahas hak waris pekerja yang meninggal dunia mulai dari ketentuan yang ada di pasal $1603 \mathrm{j}$ KUPerda dan ketentuan Pasal $1601 \mathrm{y}$ KUHPerdata. Lebih lanjut ketentuan Pasal 61 UU No. 13 tahun 2003 Tentang Ketenagakerjaan begitu juga dalam ketentuan UU No. 166 UU No. 13 tahun 2003 Tentang Ketenagakerjaan. Namun lahirnya UU No. 11 tahun 2020 tentang Cipta Kerja, menghapus ketentuan Pasal 166 UU No. 13 tahun 2003 Tentang Ketenagakerjaan, dan memuat subtansi Pasal 166 UU No. 13 tahun 2003 , dalam ketentuan Pasal 57 Peraturan Pemerintah Republik Indonesia (PP) Nomor 35 Tahun 2021 tentang Perjanjian Kerja Waktu Tertentu, Alih daya, Waktu Kerja dan Waktu Istirahat, dan Pemutusan Hubungan Kerja yang merupakan peraturan pelaksana UU Ciptaker. Penulis juga melakukan analisis terhadap penerapan hak ahliwaris yang meninggal dunia berdasarkan putusan PHI pada PN Surabaya Nomor 74/G/2014/PHI.Sby jo.Putusan MA RI No. 225 K/Pdt.Sus PHI/2015)
\end{abstract}

Kata Kunci: Hak Ahli Waris, Pekerja, Hukum Ketenagakerjaan

\title{
PENDAHULUAN
}

Hukum ketenagakerjaan atau ada juga yang menyebutkan hukum perburuhan merupakan terjemahan dari arbeidsrehct. Molenaar memberikan batasan arbeidsrecht adalah bagian hukum yang berlaku yang pada pokoknya mengatur hubungan antara buruh dan majikan, antara buruh dengan buruh dan antara buruh dengan penguasa (Imam Soepomo, 1987, 1). Kedudukan antara pengusaha dan pekerja tidaklah sama (Asri Wijayanti, 2014, 5). Secara yuridis kedudukan pengusaha dan pekerja adalah bebas, tapi secara sosial ekonomis kedudukan buruh tidak bebas (Abdul Khakim, 2013, 6). Yuridis buruh adalah bebas, prinsip negara Indonesia adalah tidak seorangpun boleh diperbudak, diperulur, diperhamba, perbudakan, perdagangan budak dan penghambaan dan segala perbuatan berupa apapun yang bertujuan kepada itu dilarang (Imam Soepomo, Op.Cit, 8).

Sosiologis buruh tidaklah bebas, sebagai orang yang tidak mempunyai bekal hidup lain daripada tenaganya, ia terpaksa bekerja pada orang lain dan majikan inilah yang pada dasarnya menentukan syarat-syarat kerja (Ibid). Mengingat kedudukan pekerja yang lebih rendah dari majikan maka perlu adanya campur tangan pemerintah memberikan perlindungan hukum (Asri Wijayanti, Op.Cit, 10). Perlindungan Hukum ketenagakerjaan bisa dilakukan, pertama; sebelum masa kerja contohnya pendidikan dan pelatihan, penempatan dan perluasan tenaga kerja. Kedua; selama masa kerja contohnya pengupahan, waktu kerja, cuti, uang transport, uang makan. Ketiga, sesudah masa kerja contohnya pemutusan hubungan kerja, pesangon, pensiun dan lainlain (Aloysius Uwiyono, 2016, 4).

Dalam melakukan hubungan kerja, tidak jarang antara pekerja dan pengusaha terjadi konflik yang berujung pada sengketa. Sengketa yang terjadi bahkan bisa berujung pada Pemutusan Hubungan Kerja (PHK). PHK berarti keadaan dimana si pekerja berhenti bekerja dari majikannya. Hakikat PHK bagi pekerja merupakan awal dari penderitaan, maksudnya bagi 
pekerja permulaan dari segala pengakhiran, permulaan dari berakhirnya mempunyai pekerjaan, permulaan dari kemampuan membiayai keperluan sehari-hari baginya dan keluarganya (Asri Wijayanti, Op.Cit, 158). Menurut teori memang pekerja berhak pula untuk mengakhiri hubungan kerja, tetapi dalam praktik majikanlah yang mengakhiri, sehingga pengakhiran itu selalu merupakan pengakhiran hubungan kerja oleh majikan (Imam Soepomo, Op.Cit, 88). Namun ada juga pemutusan kerja yang terjadi dengan sendirinya yakni ketika pekerja meninggal dunia yang diatur dalam ketentuan pasal 1603 j KUPerdata (Y.W. Sunindhia, Ninik Widayanti, 1987, 20). Dalam ketentuan Pasal 1601 y KUHPerdata juga disebutkan hubungan kerja berakhir dengan meninggalnya seorang pekerja (F.X. Djumialdji, 1992, 12). Lebih lanjut jika pekerja meninggal dunia, berakibat PHK demi hukum (Abdul Khakim, 2003, 180).

Akibat hukum dengan terjadinya peristiwa kematian seseorang secara otomatis yaitu adanya hubungan ilmu hukum yang menyangkut hak para keluarganya terhadap seluruh harta peninggalannya (Oktavia Milayani, 2017, 406) dan hal ini juga berpengaruh terhadap pekerja yang meninggal dan ahli warisnya. Berkaitan dengan itu, UU Nomor 13 Tahun 2003 tentang Ketenagakerjaan (selanjutnya disebut UUK) Pasal 61 ayat (1) menyatakan Perjanjian kerja berakhir apabila : a) Pekerja meninggal dunia. Selanjutnya Pasal 61 ayat (5) menyatakan Dalam hal pekerja/buruh meninggal dunia, ahli waris pekerja/ buruh berhak mendapatkan hak haknya sesuai dengan peraturan perundang-undangan yang berlaku atau hak hak yang telah diatur dalam perjanjian kerja, peraturan perusahaan, atau perjanjian kerja bersama.

Hak-hak pekerja ketika berakhirnya hubungan kerja secara demi hukum meliputi uang pesangon dan uang penghargaan masa kerja sebagaimana diatur dalam UUK Pasal 156 ayat (2), (3) dan (4). Namun dengan disahkannya UU No. 11 Tahun 2020 tentang Cipta Kerja (selanjutnya disebut UU Ciptaker), ketentuan Pasal 156 ayat (2) dan (3) berkaitan dengan uang pesangon dan uang penghargaan masa kerja ditentukan "paling banyak" [dalam Pasal 156 ayat (2) dan (3) UUK ditentukan "paling sedikit"], sedangkan ketentuan Pasal 156 ayat (4) huruf c pada UUK dihapus.

Selanjutnya ketentuan lebih khusus tentang hak ahli waris pekerja yang meninggal diatur dalam Pasal 166 UUK yang menyatakan "Dalam hal hubungan kerja berakhir karena pekerja/buruh meninggal dunia, kepada ahli warisnya diberikan sejumlah uang yang besar perhitungannya sama dengan perhitungan 2 (dua) kali uang pesangon sesuai ketentuan Pasal 156 ayat (2), 1 (satu) kali uang penghargaan masa kerja sesuai ketentuan Pasal 156 ayat (3), dan uang penggantian hak sesuai ketentuan Pasal 156 ayat (4). Ketentuan Pasal 166 UUK ini juga dihapus dalam UU Ciptaker, namun dihidupkan kembali dalam ketentuan Pasal 57 Peraturan Pemerintah Republik Indonesia (PP) Nomor 35 Tahun 2021 tentang Perjanjian Kerja Waktu Tertentu, Alih daya, Waktu Kerja dan Waktu Istirahat, dan Pemutusan Hubungan Kerja yang merupakan peraturan pelaksana UU Ciptaker.

Sehubungan dengan penerapan hak ahli waris pekerja yang meninggal dunia, terdapat Putusan Mahkamah Agung dalam Perkara Siti Zaenab melawan PT. Prospek Manunggal Era Industri, dikenal dengan perkara No. 225 K/Pdt.Sus PHI/2015 tanggal 4 Juni 2015 dan sebelumnya Putusan PHI pada PN Surabaya Nomor 74/G/2014/PHI.Sby tanggal 12 November 
2014. Amar putusan PHI pada PN. Surabaya Nomor 74/G/2014/PHI antara Siti Zaenab (Penggugat) melawan PT. Prospek Manunggal Era Industri (Tergugat) menyatakan :

DALAM KONPENSI :

DALAM EKSEPSI

Menolak eksepsi Tergugat seluruhnya

DALAM POKOK PERKARA :

1. Mengabulkan gugatan Penggugat untuk sebagian;

2. Menyatakan perselisihan pemutusan hubungan kerja antara Penggugat dan Tergugat sesuai ketentuan pasal 166 Undang-Undang Nomor 13 Tahun 2003 tentang Ketenagakerjaan;

3. Menghukum Tergugat membayar hak pemutusan hubungan kerja kepada Penggugat sebesar Rp.46.023.000,- - Rp.20.000.000,- = Rp.26.023.000,- (dua puluh enam juta dua puluh tiga ribu rupiah);

4. Menolak gugatan Penggugat untuk selain dan selebihnya;

\section{DALAM REKONPENSI;}

Menolak gugatan Penggugat Rekonpensi untuk seluruhnya;

DALAM KONPENSI DAN REKONPENSI;

Membebankan biaya perkara yang timbul dalam perkara ini kepada Negara sebesar Rp. 311.000,- (tiga ratus sebelas ribu rupiah).

Terhadap putusan ini PT. Prospek Manunggal Era Industri (Tergugat) melakukan upaya hukum kasasi dan diputus oleh Mahkamah Agung pada tanggal 4 Juni 2015 dengan nomor perkara No. 225K/Pdt.Sus PHI/2015 yang amarnya menyatakan :

1. Menolak permohonan kasasi dari Pemohon Kasasi PT Prospek Manunggal Era Industri tersebut

2. Membebankan biaya perkara dalam tingkat kasasi ini dibebankan kepada Negara.

Tujuan penulisan jurnal ini adalah untuk mengetahui Hak Ahli Waris Pekerja Meninggal Dunia dalam hukum ketenagakerjaan di Indonesia dan Analisis Putusan PHI pada PN Surabaya No. 74/G/2014/PHI.Sby jo. Putusan Mahkamah Agung No. 225K/Pdt.Sus PHI/2015. Manfaat teoritis dari jurnal ini memberikan pengetahuan dan pengayaan kepada semua pihak terutama berkaitan dengan hak waris pekerja yang meninggal dunia. Manfaat praktis memberikan masukan bagi pemangku kebijakan terutama tentang pentingnya pengaturan hak waris pekerja yang meninggal dunia.

\section{METODE PENELITIAN}

Penelitian yang dilakukan adalah penelitian yuridis normatif yaitu penelitian hukum yang meletakkan hukum sebagai sebuah bangunan norma (H. Salim HS dan Erlies Septiana Nurbaini, 2010, 13). Sistem norma yang dimaksud adalah mengenai asas-asas, norma, kaidah dari peraturan perundang-undangan, putusan pengadilan, perjanjian serta doktrin (ajaran). (Ibid, 34).

Penelitian yuridis normatif dilakukan untuk menganalisis berbagai peraturan yang berkaitan dengan permasalah tersebut diatas. Data yang digunakan dalam penelitian normatif ini adalah data sekunder yang terdiri dari bahan :

1. Bahan Hukum Primer yaitu 
a. UUD 1945

b. Kitab Undang-undang Hukum Perdata (KUH Perdata)

c. UU No. 12 Tahun 1964 tentang Pemutusan Hubungan Kerja di Perusahaan Swasta

d. UU No. 25 Tahun 1997 tentang Ketenagakerjaan

e. UU No. 13 Tahun 2003 tentang Ketenagakerjaan (UUK)

f. UU No. 4 Tahun 2004 tentang Penyelesaian Perselisihan Hubungan Industrial (UU PPHI)

g. UU No. 11 Tahun 2020 tentang Cipta Kerja.

h. Pemerintah Republik Indonesia Nomor 35 Tahun 2021 tentang Perjanjian Kerja Waktu Tertentu, Alih Daya, Waktu Kerja dan Waktu Istirahat, dan Pemutusan Hubungan Kerja

i. Putusan Hakim Pada Pengadilan Hubungan Industrial pada PN. Surabaya No. 74/G/2014/PHI. Sby

j. Putusan Hakim pada Mahkamah Agung No. 225K/Pdt.Sus PHI/2015

2. Bahan Hukum Sekunder antara lain
a. Buku-buku
b. Jurnal
c. Hasil-Hasil Penelitian

3. Bahan Hukum Tersier antara lain:

a. Ensiklopedia

b. Kamus Bahasa Indonesia

Setelah bahan hukum primer, sekunder dan tersier telah lengkap maka diolah dan dianalisa secara kualitatif. Analisa ini dilakukan dengan cara menganalisa bahan hukum berdasarkan konsep, teori, pendapat pakar ataupun pandangan penulis sendiri, dan dilakukan interprestasi untuk menarik kesimpulan. Pendekatan yang digunakan dalam tulisan ini adalah pendekatan undang-undang dan pendekatan kasus.

\section{HASIL DAN PEMBAHASAN}

Hak ahli waris pekerja meninggal dunia dalam hukum ketenagakerjaan.

Masalah yang sangat penting dalam hukum ketenagakerjaan salah satunya adalah Pemutusan Hubungan Kerja (PHK). Berakhirnya hubungan kerja bagi pekerja berarti kehilangan mata pencaharian yang berarti pula permulaan masa pengangguran dengan segala akibatnya (Sendjun H. Manulang, 1987, 106).

Ada 4 (empat) istilah dalam PHK yaitu: (Sendjun Manulang, Ibid, 107).

1. Termination, yaitu putusnya hubungan kerja karena selesainya/berakhirnya kontrak kerja.

2. Dismissal, yaitu putusnya hubungan kerja karena tindakan indisipliner.

3. Redudancy, yaitu pemutusan hubungan kerja yang diakibatkan dengan perkembangan teknologi.

4. Retrenchment, yaitu Pemutusan hubungan kerja yang dikaitkan dengan masalah ekonomi, seperti resesi ekonomi, masalah pemasaran dan lain sebagainya, sehingga perusahaan tersebut tidak dapat/tidak mampu untuk memberikan upah kepada tenaga kerja/kawannya. 
PHK adalah perselisihan yang timbul karena tidak adanya kesesuaian pendapat mengenai pengakhiran hubungan kerja yang dilakukan salah satu pihak (Pasal 1 angka 4 UU PPHI. Sedangkan menurut (Pasal 1 angka 25) UUK, PHK adalah pengakhiran hubungan kerja karena suatu hal tertentu yang mengakibatkan berakhirnya hak dan kewajiban antara pekerja/buruh dan pengusaha. Jika dibandingkan, pengertian pemutusan hubungan kerja dalam ketentuan Pasal 1 angka 4 UU PPHI seolah-olah pemutusan hubungan hubungan kerja hanya dilakukan oleh salah satu pihak, dalam hal ini bisa dilakukan oleh majikan/pengusaha atau pekerja/buruh. Ketentuan Pasal 1 angka 25 UUK lebih menekankan pada ada suatu hal tertentu (peristiwa) yang mengakibatkan berakhirnya hak dan kewajiban antara pihak pekerja/buruh dan pihak majikan/pengusaha.

Moh Syaufii Syamsuddin, berakhirnya hubungan kerja terbagi lima macam: (Abdul Khakim, 2014, 178-179).

1. Berakhir demi hukum yaitu berakhir karena perjanjian, diakhiri dalam masa percobaan atas permintaan pekerja, pekerja meninggal dunia

2. Keadaan yang melekat pada pribadi pekerja yaitu sakit selama lebih dari satu tahun, cacat total tetap, karena terjadinya perkawinan

3. Berkenaan dengan kelakuan pekerja, kesalahan berat dan diluar kesalahan berat.

4. Berkenaan dengan Tindakan Pengusaha, sebagaimana diatura dalam Pasal 169 UUK.

5. Berkenaan dengan jalannya perusahaan yaitu perusahaan tutup, perusahaan melakukan efisiensi dan perusahaan pailit.

Sementara menurut Abdul Khakim secara teoritis yuridis terbagi dalam empat macam, yaitu: (Abdul Khakim, Ibid, 178).

1. PHK demi hukum;

2. PHK oleh pengadilan;

3. PHK oleh pekerja/buruh;

4. PHK oleh pengusaha;

PHK demi hukum adalah PHK bukan diputuskan oleh pihak buruh/pekerja juga bukan oleh pihak pengusaha/majikan dan juga bukan diputuskan oleh pihak pengadilan, tetapi merupakan PHK dengan sendirinya tanpa adanya tindakan dari semua pihak baik oleh buruh, majikan, maupun pengadilan (Abdussalam, Adri Desasfuryanto, Op.Cit. 95). PHK demi hukum salah satunya disebabkan pekerja meninggal dunia. Meninggalnya pekerja secara otomatis menyebabkan berakhirnya hubungan kerja. Meskipun hubungan kerja berakhir dengan pekerja yang meninggal, namun ahli waris pekerja yang meninggal akan menerima hak waris dari pekerja yang meninggal.

Dalam ketentuan Pasal 1603 e KUH Perdata dinyatakan hubungan kerja berakhir demi hukum, jika habis waktunya yang ditetapkan dalam perjanjian atau dalam peraturan undangundang atau jika semuanya itu tidak ada, menurut kebiasaan. Pemberitahuan tentang PHK dalam hal ini hanya diperlukan, 1. Jika hal itu dijanjikan dalam surat perjanjian atau dalam reglemen, 2. Jika menurut peraturan undang-undang atau menurut kebiasaan, juga dalam hal lamanya hubungan kerja ditetapkan sebelumnya, diharuskan adanya pemberitahuan tentang pemutusan itu 
dari kedua belah pihak, dalam hal yang diperbolehkan, tidak mengadakan penyimpangan dengan perjanjian tertulis atau reglemen. Sementara Pasal 1603 j menyatakan Hubungan kerja berakhir dengan meninggalnya buruh. Jika dilihat ketentuan Pasal 1603 e maka tidak disyaratkan adanya pernyataan pengakhiran atau adanya tenggang waktu pengakhiran atau semuanya tidak ada menurut kebiasaan. Namun dalam ketentuan Pasal 1603 j, lebih tegas dinyatakan soal berakhirnya hubungan kerja karena pekerja meninggal dunia. Kewajiban pekerja melakukan pekerjaan tidak dapat diwariskan akibat meninggalnya pekerja, maka terjadi PHK demi hukum. Dalam hal ini tidak ada persoalan pesangon, jasa maupun ganti rugi melainkan mendapat penggantian kerugian menurut UU Kecelakaan atau Astek atau mendapat Asuransi Kematian dalam Astek dan sebagainya (FX Djumialdji, 1981, 12). Kewajiban yang ada pada waktu berakhirnya adanya hubungan kerja merupakan beban bagi buruh, seperti mengosongkan rumah perusahaan, beralih kepada ahli warisnya. Mereka ini sebagai yang menerima waris, yaitu segala hak dan kewajiban, wajib memenuhi kewajiban semacam itu atas dasar perjanjian kerja dan majikan dapat menuntutnya dari ahli waris. (Y.W Sunindhia, Ninik Widiyanti, Op.Cit, 20). Dengan ketentuan ini ada hak dan kewajiban ahli waris dari pekerja yang meninggal dunia, namun berkaitan dengan hak yang diterima ahli waris pekerja meninggal dunia tidak dijelaskan secara spesifik. Lain halnya, jika meninggalnya majikan, maka hubungan kerja tidak berakhir kecuali bila watak hubungan kerja atau perjanjian sendiri yang menghendaki sebaliknya. Ketentuan meninggalnya majikan tidak memutuskan hubungan kerja merupakan cetusan dari prinsip yang lebih tinggi bahwa pemindahtanganan suatu perusahaan tidak memutuskan hubungan kerja. (Imam Soepomo, Op.Cit, 130). Ketentuan tersebut diperlemah oleh ketentuan ahli waris setelah menerima penerusan hubungan kerja itu mengakhiri hubungan kerja itu (Ibid). Ahli waris majikan di satu pihak dengan pekerja dianggap ada perjanjian kerja untuk waktu tidak tertentu, oleh karena itu baik ahli waris majikan maupun pekerja dapat memutuskan hubungan kerja dengan pernyataan pengakhiran dan mengingat tenggang pengakhiran FX. Djumialdji, Op.Cit, 12-13). Ketentuan Pasal 1601 sampai dengan 1603 KUHPerdata dicabut dengan lahirnya UU No. 12 Tahun 1964 tentang Pemutusan Hubungan Kerja di Perusahaan Swasta. Dalam UU No 12 Tahun 1964, wewenang ahli waris (majikan) sangat dibatasi, karena ahli waris harus meminta izin terlebih dahulu dari Panitia Penyelesaian Perselisihan Perburuhan Daerah/Pusat (P4D/P4P) untuk mengadakan PHK. Ketentuan UU No. 12 Tahun 1964 juga tidak secara jelas menyatakan apakah ada hak ahli waris yang meninggal dunia karena ketentuan ini lebih mengepankan harus adanya izin PHK.

Ketentuan hak ahli waris pekerja yang meninggal dapat ditemui dalam Pasal 21 ayat (1) dan (4) UU No. 25 Tahun 1997 tentang Ketenagakerjaan yang menyatakan; ayat (1) : Perjanjian kerja berakhir apabila : a. pekerja meninggal dunia. Ayat (4) Dalam hal pekerja meninggal dunia, ahli waris pekerja berhak mendapatkan hak-haknya sesuai dengan peraturan perundangundangan yang berlaku atau hak-hak yang telah diatur dalam perjanjian kerja, peraturan perusahaan, atau kesepakatan kerja bersama. UU Nomor 25 Tahun 1997 ini tidak jadi diundangkan dan dicabut oleh UUK. 
Selanjutnya ketentuan ahli waris pekerja yang meninggal dunia diatur dalam UUK Pasal 61 ayat (1) menyatakan Perjanjian kerja berakhir apabila : a) Pekerja meninggal dunia. Selanjutnya Pasal 61 ayat (5) menyatakan "Dalam hal pekerja/buruh meninggal dunia, ahli waris pekerja/ buruh berhak mendapatkan hak haknya sesuai dengan peraturan perundang-undangan yang berlaku atau hak hak yang telah diatur dalam perjanjian kerja, peraturan perusahaan, atau perjanjian kerja bersama. Ketentuan lebih khusus tentang hak ahli waris pekerja yang meninggal diatur dalam Pasal 166 UUK yang menyatakan "Dalam hal hubungan kerja berakhir karena pekerja/buruh meninggal dunia, kepada ahli warisnya diberikan sejumlah uang yang besar perhitungannya sama dengan perhitungan 2 (dua) kali uang pesangon sesuai ketentuan Pasal 156 ayat (2), 1 (satu) kali uang penghargaan masa kerja sesuai ketentuan Pasal 156 ayat (3), dan uang penggantian hak sesuai ketentuan Pasal 156 ayat (4).

Ketentuan Pasal 166 UUK ini kemudian dihapus dalam UU Ciptaker, namun dihidupkan kembali dalam ketentuan Pasal 57 Peraturan Pemerintah Republik Indonesia (PP) Nomor 35 Tahun 2021 tentang Perjanjian Kerja Waktu Tertentu, Alih daya, Waktu Kerja dan Waktu Istirahat, dan Pemutusan Hubungan Kerja. Ketentuan Pasal 57 PP No. 35 Tahun 2021 menyatakan "Pemutusan Hubungan Kerja karena alasan Pekerja/Buruh meninggal dunia maka kepada ahli warisnya diberikan sejumlah uang yang perhitungannya sama dengan: a. uang pesangon Pasal 40 ayat (2), sebesar 2 (dua) kali ketentuan, b. uang penghargaan masa kerja sebesar 1 (satu) kali ketentuan Pasal 40 ayat (3); dan c. uang penggantian hak sesuai ketentuan Pasal 40 ayat (4).

\section{Besaran Hak ahli waris pekerja yang meninggal dunia.}

Pengaturan lebih lanjut menyangkut penyebab PHK demi hukum, terdapat pada Pasal 154 huruf d UUK [diubah menjadi Pasal 154 A ayat (1) huruf n UU Ciptaker], adalah pekerja/buruh meninggal dunia [lihat juga ketentuan Pasal 61 ayat (1) huruf d UUK yang juga telah diubah oleh Pasal 61 UU Ciptaker]. Konsekwensinya ada pada Pasal 166 UUK, maka kepada ahli warisnya diberikan sejumlah uang yang besar perhitungannya sama dengan perhitungan 2 (dua) kali uang pesangon sesuai ketentuan Pasal 156 ayat (2), 1 (satu) kali uang penghargaan masa kerja sesuai ketentuan Pasal 156 ayat (3), dan uang penggantian hak sesuai ketentuan Pasal 156 ayat (4). Ketentuan Pasal 166 UUK dihapus dengan adanya UU Cipta Kerja. Meskipun ketentuan Pasal 166 UUK sudah dihapus oleh UU Cipta Kerja, namun yang anehnya ketentuan tersebut kembali muncul dalam Pasal 57 Peraturan Pemerintah No. 35 tahun 2021 tentang Perjanjian Kerja Waktu Tertentu, Alih Daya, Waktu Kerja dan Waktu Istirahat, dan Pemutusan Hubungan Kerja. Itu artinya ketentuan Pasal ini mengalami "penurunan derajat" dalam hirarki peraturan perundangundangan di Indonesia. Pengaturan tentang besaran hak yang diterima ahli waris akibat pekerja meninggal dunia sehingga terjadi PHK demi hukum di Indonesia baru ditemui dalam UUK.

Sebagaimana telah disinggung sebelumnya, ketentuan tersebut diatur dalam Pasal 166 UUK, sedangkan untuk besarannya merujuk kepada Pasal 156 ayat (2), (3) dan (4) UUK yang kemudian juga diubah oleh ketentuan Pasal 81 angka 44 Bagian Kedua Bab IV Ketenagakerjaan UU Cipta Kerja. Ketentuan Pasal 166 UUK dihapus oleh UU Cipta Kerja, dan muncul kembali 
dalam Pasal 57 PP No. 35 Tahun 2021 tentang Perjanjian Kerja Waktu Tertentu, Alih Daya, Waktu Kerja dan Waktu Istirahat, dan Pemutusan Hubungan Kerja. Ketentuan Pasal 57 ini juga merujuk kepada Pasal 40 ayat (2), (3) dan (4). Dari substansi yang ada, terjadi penurunan besaran jumlah uang yang dapat diterima oleh ahli waris pekerja yang meninggal dunia akibat digantinya frasa paling sedikit menjadi paling banyak pada Pasal 156 ayat (2) UUK (yang diubah oleh Pasal 81 angka 44 Bagian Kedua Bab IV Ketenagakerjaan UU Cipta Kerja) dan dihapusnya ketentuan Pasal 156 ayat (4) huruf c UUK. Lebih jelasnya dapat dilihat dalam tabel berikut.

Tabel. 1

Hak ahli waris

\begin{tabular}{|c|c|}
\hline Pasal 166 UUK & Pasal 57 PP No. 35 Tahun 2021 \\
\hline $\begin{array}{l}\text { Dalam hal hubungan kerja berakhir } \\
\text { karena pekerja/buruh meninggal dunia, } \\
\text { kepada ahli warisnya diberikan sejumlah } \\
\text { uang yang besar perhitungannya sama } \\
\text { dengan perhitungan } 2 \text { (dua) kali uang } \\
\text { pesangon sesuai ketentuan Pasal } 156 \text { ayat (2), } \\
1 \text { (satu) kali uang penghargaan masa kerja } \\
\text { sesuai ketentuan Pasal } 156 \text { ayat (3), dan uang } \\
\text { penggantian hak sesuai ketentuan Pasal } 156 \\
\text { ayat (4). }\end{array}$ & $\begin{array}{l}\text { Pemutusan Hubungan Kerja karena } \\
\text { alasan Pekerja/Buruh meninggal dunia maka } \\
\text { kepada ahli warisnya diberikan sejumlah } \\
\text { uang yang perhitungannya sama dengan : } \\
\text { a. uang pesangon Pasal } 40 \text { ayat (2) sebesar } 2 \\
\text { (dua) kali ketentuan } \\
\text { b. uang penghargaan masa kerja sebesar } 1 \\
\text { (satu) kali ketentuan Pasal } 40 \text { ayat (3); } \\
\text { dan } \\
\text { c. uang penggantian hak sesuai ketentuan } \\
\text { Pasal } 40 \text { ayat (4). }\end{array}$ \\
\hline
\end{tabular}

Sumber : UUK, PP 35 Tahun 2021

Tabel. 2

Besaran uang pesangon, penghargaan masa kerja dan uang penggantian hak

\begin{tabular}{|l|lr|rrr|}
\hline \multicolumn{2}{|c|}{ Pasal 156 UUK } & \multicolumn{2}{|c|}{ Perubahan Pasal 156 UUK } \\
berdasarkan UU Ciptaker
\end{tabular}




\begin{tabular}{|c|c|c|c|}
\hline & Isal 156 UUK & $\begin{array}{l}\text { Perubahan Pasal } 156 \text { UUK } \\
\text { berdasarkan UU Ciptaker }\end{array}$ & $\begin{array}{l}\text { Pasal } 40 \text { PP No. } 35 \text { Tahun } \\
2021\end{array}$ \\
\hline b. & $\begin{array}{l}\text { masa kerja kurang dari } \\
1 \text { (satu) tahun, } 1 \text { (satu) } \\
\text { bulan upah; } \\
\text { masa kerja } 1 \text { (satu) } \\
\text { tahun atau lebih tetapi } \\
\text { kurang dari } 2 \text { (dua) } \\
\text { tahun, } 2 \text { (dua) bulan } \\
\text { upah; } \\
\text { masa kerja } 2 \text { (dua) } \\
\text { tahun atau lebih tetapi } \\
\text { kurang dari } 3 \text { (tiga) } \\
\text { tahun, } 3 \text { (tiga) bulan } \\
\text { upah; } \\
\text { masa kerja } 3 \text { (tiga) } \\
\text { tahun atau lebih tetapi } \\
\text { kurang dari } 4 \text { (empat) } \\
\text { tahun, } 4 \text { (empat) bulan } \\
\text { upah; } \\
\text { masa kerja } 4 \text { (empat) } \\
\text { tahun atau lebih tetapi } \\
\text { kurang dari } 5 \text { (lima) } \\
\text { tahun, } 5 \text { (lima) bulan } \\
\text { upah; } \\
\text { masa kerja } 5 \text { (lima) } \\
\text { tahun atau lebih, tetapi } \\
\text { kurang dari } 6 \text { (enam) } \\
\text { tahun, } 6 \text { (enam) bulan } \\
\text { upah; } \\
\text { masa kerja } 6 \text { (enam) } \\
\text { tahun atau lebih tetapi } \\
\text { kurang dari } 7 \text { (tujuh) } \\
\text { tahun, } 7 \text { (tujuh) bulan } \\
\text { upah. } \\
\text { masa kerja } 7 \text { (tujuh) } \\
\text { tahun atau lebih tetapi } \\
\text { kurang } \\
\text { (delapan) tahun, } \\
\text { (delapan) bulan upah; }\end{array}$ & $\begin{array}{l}\text { ketentuan sebagai berikut: } \\
\text { a. masa kerja kurang dari } 1 \\
\text { (satu) tahun, } 1 \text { (satu) } \\
\text { bulan upah; } \\
\text { b. masa kerja } 1 \text { (satu) } \\
\text { tahun atau lebih tetapi } \\
\text { kurang dari } 2 \text { (dua) } \\
\text { tahun, } 2 \text { (dua) bulan } \\
\text { upah; } \\
\text { c. masa kerja } 2 \text { (dua) tahun } \\
\text { atau lebih tetapi kurang } \\
\text { dari } 3 \text { (tiga) tahun, } 3 \\
\text { (tiga) bulan upah; } \\
\text { d. masa kerja } 3 \text { (tiga) tahun } \\
\text { atau lebih tetapi kurang } \\
\text { dari } 4 \text { (empat) tahun, } 4 \\
\text { (empat) bulan upah; } \\
\text { e. masa kerja } 4 \text { (empat) } \\
\text { tahun atau lebih tetapi } \\
\text { kurang dari } 5 \text { (lima) } \\
\text { tahun, } 5 \text { (lima) bulan } \\
\text { upah; } \\
\text { f. masa kerja } 5 \text { (lima) } \\
\text { tahun atau lebih, tetapi } \\
\text { kurang dari } 6 \text { (enam) } \\
\text { tahun, } 6 \text { (enam) bulan } \\
\text { upah; } \\
\text { g. masa kerja } 6 \text { (enam) } \\
\text { tahun atau lebih tetapi } \\
\text { kurang dari } 7 \text { (tujuh) } \\
\text { tahun, } 7 \text { (tujuh) bulan } \\
\text { upah; } \\
\text { masa kerja } 7 \text { (tujuh) } \\
\text { tang }\end{array}$ & $\begin{array}{l}\text { dengan ketentuan } \\
\text { sebagai berikut: } \\
\text { a. masa kerja kurang dari } \\
\text { 1 (satu) tahun, } 1 \text { (satu) } \\
\text { bulan Upah; } \\
\text { b. masa kerja } 1 \text { (satu) } \\
\text { tahun atau lebih tetapi } \\
\text { kurang dari } 2 \text { (dua) } \\
\text { tahun, } 2 \text { (dua) bulan } \\
\text { Upah; } \\
\text { c. masa kerja } 2 \text { (dua) } \\
\text { tahun atau lebih tetapi } \\
\text { kurang dari } 3 \text { (tiga) } \\
\text { tahun, } 3 \text { (tiga) bulan } \\
\text { Upah; } \\
\text { d. masa kerja } 3 \text { (tiga) } \\
\text { tahun atau lebih tetapi } \\
\text { kurang dari } 4 \text { (empat) } \\
\text { tahun, } 4 \text { (empat) bulan } \\
\text { Upah; } \\
\text { e. masa kerja } 4 \text { (empat) } \\
\text { tahun atau lebih tetapi } \\
\text { kurang dari } 5 \text { (lima) } \\
\text { tahun, } 5 \text { (lima) bulan } \\
\text { Upah; } \\
\text { f. masa kerja } 5 \text { (lima) } \\
\text { tahun atau lebih, tetapi } \\
\text { kurang dari } 6 \text { (enam) } \\
\text { tahun, } 6 \text { (enam) bulan } \\
\text { Upah; } \\
\text { g. masa kerja } 6 \text { (enam) } \\
\text { tahun atau lebih tetapi } \\
\text { kurang dari7 } 7 \text { (tujuh) } \\
\text { tahun, } 7 \text { tujuh) bulan } \\
\text { upang dari } 8 \text { (delapan) }\end{array}$ \\
\hline
\end{tabular}




\begin{tabular}{|c|c|c|}
\hline 36 UUK & $\begin{array}{l}\text { Perubahan Pasal } 156 \text { UUK } \\
\text { berdasarkan UU Ciptaker }\end{array}$ & $\begin{array}{c}\text { Pasal } 40 \text { PP No. } 35 \text { Tahun } \\
2021\end{array}$ \\
\hline $\begin{array}{l}\text { i. masa kerja } 8 \text { (delapan) } \\
\text { tahun atau lebih, } 9 \\
\text { (sembilan) bulan upah. } \\
\text { 3. Perhitungan } \\
\text { penghargaan masa kerja } \\
\text { sebagaimana dimaksud } \\
\text { dalam ayat (1) ditetapkan } \\
\text { sebagai berikut: } \\
\text { a. masa kerja } 3 \text { (tiga) } \\
\text { tahun atau lebih tetapi } \\
\text { kurang dari } 6 \text { (enam) } \\
\text { tahun, 2 (dua) bulan } \\
\text { upah; } \\
\text { b. } \text { masa kerja } 6 \text { (enam) } \\
\text { tahun atau lebih tetapi } \\
\text { kurang dari } 9 \\
\text { (sembilan) tahun, } 3 \\
\text { (tiga) bulan upah; } \\
\text { masa kerja } 9 \\
\text { (sembilan) tahun atau } \\
\text { lebih tetapi kurang dari }\end{array}$ & 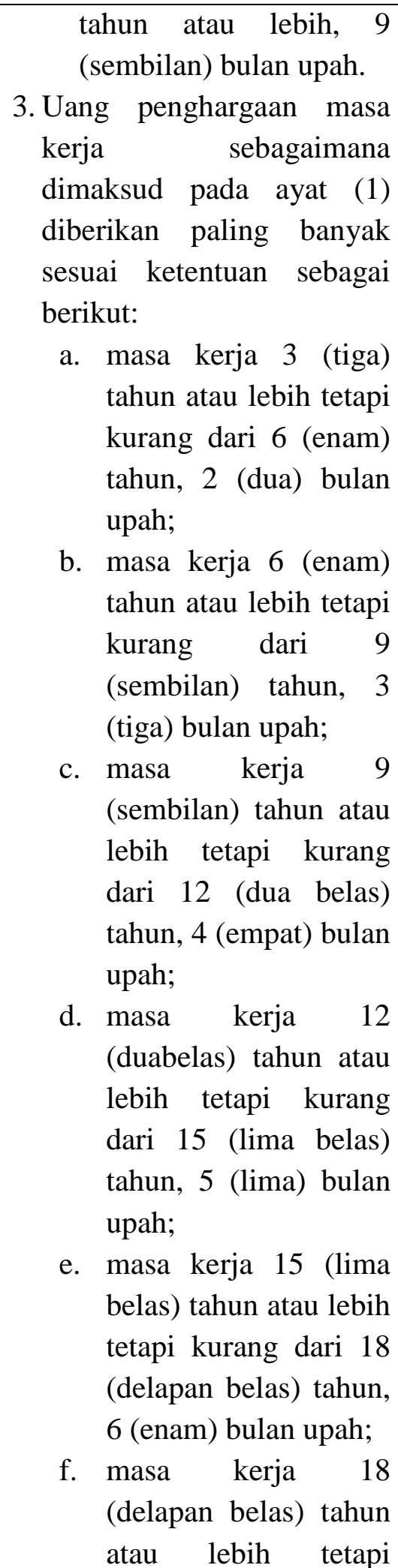 & $\begin{array}{l}\text { tahun, } 8 \text { (delapan) } \\
\text { bulan Upah; dan } \\
\text { i. masa kerja } 8 \text { (delapan) } \\
\text { tahun atau lebih, } 9 \\
\text { (sembilan) bulan Upah. } \\
\text { 3. Uang penghargaan masa } \\
\text { kerja sebagaimana } \\
\text { dimaksud pada ayat (1) } \\
\text { diberikan dengan } \\
\text { ketentuan sebagai } \\
\text { berikut: } \\
\text { a. masa kerja } 3 \text { (tiga) } \\
\text { tahun atau lebih tetapi } \\
\text { kurang dari } 6 \text { (enam) } \\
\text { tahun, } 2 \text { (dua) bulan } \\
\text { Upah; } \\
\text { b. masa kerja } 6 \text { tahun atau } \\
\text { lebih tetapi kurang dari } \\
\text { 9 (sembilan) tahun, } 3 \\
\text { bulan upah; } \\
\text { c. masa kerja 9 (sembilan) } \\
\text { tahun atau lebih tetapi } \\
\text { kurang dari } 12 \text { (dua } \\
\text { belas) tahun, } 4 \text { (empat) } \\
\text { bulan Upah; } \\
\text { d. masa kerja } 12 \text { (dua } \\
\text { belas) tahun atau lebih } \\
\text { tetapi kurang dari } 15 \\
\text { (lima belas) tahun, } 5 \\
\text { (lima) bulan Upah; } \\
\text { tetapi kurang dari } 21 \\
\text { e. masa kerja } 15 \text { (lima } \\
\text { belas) tahun atau lebih } \\
\text { tetapi kurang dari } 18 \\
\text { (delapan belas) tahun, } 6 \\
\text { manan Upah; }\end{array}$ \\
\hline
\end{tabular}




\begin{tabular}{|c|c|c|}
\hline Pasal 156 UUK & $\begin{array}{l}\text { Perubahan Pasal } 156 \text { UUK } \\
\text { berdasarkan UU Ciptaker }\end{array}$ & $\begin{array}{l}\text { Pasal } 40 \text { PP No. } 35 \text { Tahun } \\
2021\end{array}$ \\
\hline 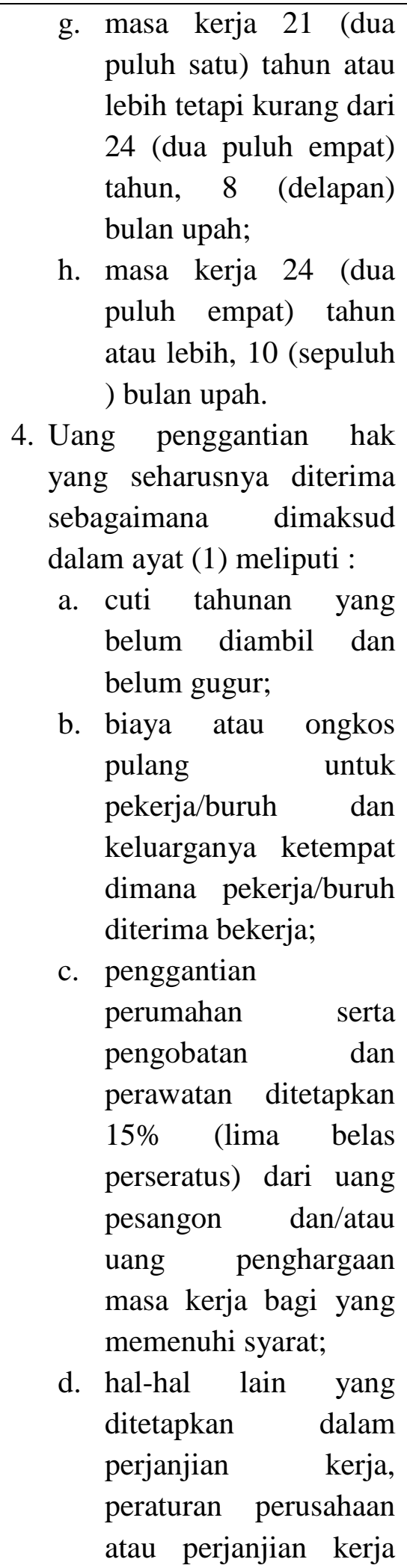 & 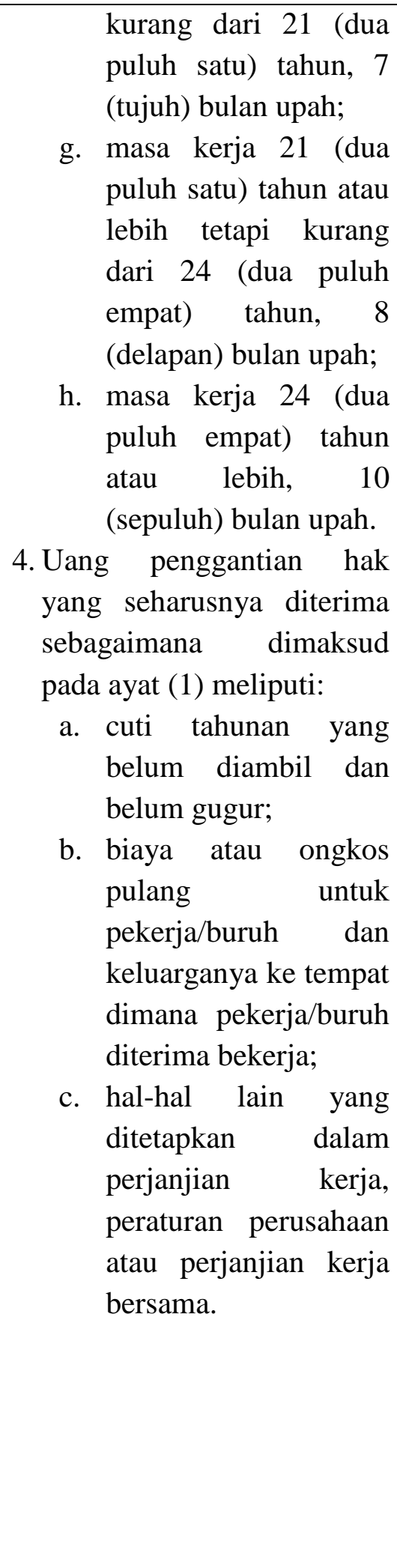 & $\begin{array}{l}\text { (dua puluh satu) tahun, } \\
7 \text { (tujuh) bulan Upah; } \\
\text { g. masa kerja } 21 \text { (dua } \\
\text { puluh satu) tahun atau } \\
\text { lebih tetapi kurang dari } \\
24 \text { (dua puluh empat) } \\
\text { tahun, } 8 \text { (delapan) } \\
\text { bulan Upah; dan } \\
\text { h. masa kerja 24 (dua } \\
\text { puluh empat) tahun } \\
\text { atau lebih, 10 (sepuluh) } \\
\text { bulan Upah. } \\
\text { Uang penggantian hak } \\
\text { yang seharusnya diterima } \\
\text { sebagaimana dimaksud } \\
\text { pada ayat (1) meliputi: } \\
\text { a. cuti tahunan yang } \\
\text { belum diambil dan } \\
\text { belum gugur; } \\
\text { b. biaya atau ongkos } \\
\text { pulang } \\
\text { Pekerja/Buruh } \\
\text { keluarganya ke tempat } \\
\text { dimana Pekerja/Buruh } \\
\text { diterima bekerja; dan } \\
\text { c. hal-hal lain yang } \\
\text { ditetapkan dalam } \\
\text { Perjanjian } \\
\text { Peraturan Perusahaan, } \\
\text { atau Perjanjian Kerja } \\
\text { Bersama. }\end{array}$ \\
\hline
\end{tabular}




\begin{tabular}{|c|c|c|}
\hline Pasal 156 UUK & $\begin{array}{l}\text { Perubahan Pasal } 156 \text { UUK } \\
\text { berdasarkan UU Ciptaker }\end{array}$ & $\begin{array}{c}\text { Pasal } 40 \text { PP No. } 35 \text { Tahun } \\
2021\end{array}$ \\
\hline $\begin{array}{l}\text { bersama. } \\
\text { 5. Perubahan } \\
\text { uang } \\
\text { perhitungan } \\
\text { penghargaan masa kerja, } \\
\text { dan uang penggantian hak } \\
\text { sebagaimana dimaksud } \\
\text { dalam ayat (2), ayat (3), } \\
\text { dan ayat (4) ditetapkan } \\
\text { dengan } \\
\text { Pemerintah. }\end{array}$ & $\begin{array}{l}\text { 5. Ketentuan lebih lanjut } \\
\text { mengenai pemberian uang } \\
\text { pesangon, } \\
\text { penghargaan masa kerja, } \\
\text { dan uang penggantian hak } \\
\text { sebagaimana dimaksud } \\
\text { pada ayat (2), ayat (3), dan } \\
\text { ayat (4) diatur dengan } \\
\text { Peraturan Pemerintah. }\end{array}$ & \\
\hline
\end{tabular}

Sumber : UUK, UU Ciptaker, PP No. 35 Tahun 2021

Analisa Putusan Putusan PHI pada PN Surabaya Perkara Nomor 74/G/2014/PHI.Sby tanggal 12 November 2014 dan Putusan Mahkamah Agung Republik Indonesia Perkara No. 225 K/Pdt.Sus PHI/2015 tanggal 4 Juni 2015.

\section{Para Pihak}

a. Siti Zaenab, Warga Negara Indonesia, jenis kelamin perempuan, beragama Islam, beralamat di Dusun Manduro RT.01/RW.01 Desa Manduro Manggung Gajah Kecamatan Ngoro Kabupaten Mojokerto, yang dalam perkara ini diwakili oleh Kuasanya yang bernama Sukarji, S.H., M.H., Agus Subiyanto, S.H., M.H., dan Misti’anah, S.H., M.H., Para Advokat pada kantor Advokat \& Konsultan Hukum "Sukarji, S.H. \& Partner selaku Penggugat.

b. PT. Prospek Manunggal Era Industri, beralamat di Desa Watesnegoro Kecamatan Ngoro Kabupaten Mojokerto, yang dalam perkara ini diwakili oleh Kuasanya yang bernama : Iswanto, S.H, Dedy S. Mulyono, S.H, Budi Tjahjono, S.H, Eddy Purwanto, S.H, Selamet Untung, S.H., Drs. Asnan Ashari, S.H., M.H., Para Advokat dan Konsultan Hukum pada kantor Advokat Delta Law Firm selaku Tergugat.

\section{Duduk Perkara Singkat}

\section{a. Gugatan}

- Tanggal surat gugatan dan pendaftaran ke PHI adalah tanggal 14 Juli 2014

- Penggugat sebagai ahli waris Sholehuddin (alm), yang merupakan karyawan PT. Prospek Manunggal Era Industri di Desa Watesnegoro Kecamatan Ngoro Kabupaten Mojokerto sejak bulan Desember 2001 yang meninggal tanggal 2 Desember 2013

- Almarhum telah bekerja sebagai karyawan Tergugat sejak bulan Desember 2001 sampai dengan tanggal 2 Desember 2013 (masa kerja 12 tahun), upah terakhir perbulan sebesar Rp.1.740.000,- (satu juta tujuh ratus empat puluh ribu rupiah); 
- Almarhum Sholehuddin meninggalkan seorang istri dengan identitas sebagaimana tersebut pada identitas Penggugat dan seorang anak perempuan bernama Dian Fatmawati lahir di Mojokerto tanggal 26 Januari 2000, belum kawin, beragama Islam, alamat mengikuti Penggugat;

- Pada tanggal 7 Desember 2013 Tergugat melalui Bu Ririn sebagai personalia menyerahkan uang santunan dengan menyampaikan kata-kata kepada Penggugat "ini uang santunan dari perusahaan" sebesar Rp.20.000.000,- (duapuluh juta rupiah) dan Penggugat diminta tandatangan kwitansi sebagai buktipenyerahan uang;

- Bahwa pada tanggal 13 Desember 2013 Penggugat mendatangi Tergugat untuk meminta haknya sebagai ahli waris, Tergugat mengatakan bahwa uang Rp.20.000.000,- (dua puluh juta rupiah) tersebut adalah merupakan uang pesangon Penggugat sebagai ahli waris almarhum Sholehuddin;

- Penggugat sudah meminta dilakukan Bipartit sebanyak 2 kali namun ditolak oleh Tergugat;

- Mediator di Dinas Tenaga Kerja dan Transmigrasi Kabupaten Mojokerto namun mengeluarkan surat anjuran dengan Nomor : 565/443/416.105/2014 tertanggal 17 April 2014, atas anjuran tersebut di atas Penggugat menyatakan menolak;

- Penggugat menuntut haknya sesuai ketentuan pasal 166 Undang-Undang Nomor 13 Tahun 2003 tentang Ketenagakerjaan yaitu 2 (dua) kali uang pesangon sesuai ketentuan pasal 156 ayat (2), 1 (satu) kali uang penghargaan masa kerja sesuai ketentuan pasal 156 ayat (3) dan uang penggantian hak sesuai ketentuan pasal 156 ayat (4)" yaitu sejumlah Rp.45.793.000,- (empat puluh lima juta tujuh ratus sembilan puluh tiga ribu rupiah) dengan perincian :

Uang pesangon

Uang penghargaan masa kerja

Uang penggantian hak

Total

$$
\begin{array}{rlr}
9 \times 2 \times \text { Rp. } 1.740 .000,- & =\text { Rp.31.320.000,- } \\
5 \times \quad \text { Rp. } 1.740 .000,- & =\text { Rp. } 8.500 .000,- \\
15 \% \text { x Rp. } 39.820 .000,- & =\text { Rp. 5.973.000,- } \\
=\text { Rp.45.793.000,- }
\end{array}
$$

- Tergugat hanya membayar sejumlah uang sebesar Rp.20.000.000,- (dua puluh juta rupiah), di samping itu dengan menggunakan kwitansi sebagai bukti penyelesaian perselisihan

- Penggugat meminta Tergugat untuk membayar kekurangan "sejumlah uang" sebesar Rp.25.793.000,- (dua puluh lima juta tujuh ratus sembilan puluh tiga ribu rupiah) dengan perincian (Rp.45.793.000,- - Rp.20.000.000,- = Rp.25.793.000,-);

\section{b. Petitum Gugatan}

1) Mengabulkan gugatan Penggugat untuk seluruhnya;

2) Menyatakan hubungan kerja antara Tergugat dengan almarhum Sholehuddin putus karena pekerja meninggal dunia dengan menerima sejumlah uang sebagaimana ketentuan pasal 166 Undang-Undang Nomor 13 Tahun 2003 tentang Ketenagakerjaan;

3) Menyatakan Tergugat telah melakukan perbuatan yang bertentangan dengan UndangUndang Nomor 2 Tahun 2004 tentang Penyelesaian Perselisihan Hubungan Industrial; 
4) Menghukum Tergugat untuk membayar kekurangan "sejumlah uang" secara tunai dan sekaligus sebesar Rp.25.793.000,- (dua puluh lima juta tujuh ratus sembilan puluh tiga ribu rupiah) dengan perincian (Rp.45.793.000,- - Rp.20.000.000,- = Rp.25.793.000,-);

5) Menyatakan putusan ini dapat dijalankan terlebih dahulu walaupun ada upaya kasasi; Atau apabila Pengadilan Hubungan Industrial pada Pengadilan Negeri Surabaya berpendapat lain, mohon putusan yang seadil-adilnya (ex aequo et bono) untuk kepentingan Penggugat;

\section{c. Eksepsi dan Jawaban}

- PHI tidak berwenang mengadili karena antara Siti Zaenab dan PT. Prospek Manunggal Era Industri tidak terdapat hubungan kerja;

- Dalam perkara ini pihak-pihak yang berperkara adalah Siti Zaenab (selaku Penggugat Prinsipal) melawan PT. Prospek Manunggal Era Industri (selaku Tergugat);

- Dalam perkara aquo bisa jadi (mungkin benar) bahwa Siti Zaenab (Penggugat prinsipal) adalah ahli waris dari Almarhum Sholehuddin yang dulu sebelum meninggalnya adalah pekerja pada perusahaan Tergugat, sehingga dalam perkara ini perlu diketahui terlebih dahulu kebenarannya apakah benar Penggugat (Siti Zaenab) adalah ahli waris dari almarhum Sholehuddin;

- Bahwa jikapun diasumsikan benar terdapat "Hak" dari Penggugat (Siti Zaenab), maka hak tersebut adalah merupakan "hak keperdataan" yang "Alas Hak-nya" adalah didasarkan pada hubungan kewarisan bukan hubungan kerja;

- Bahwa dalam pemeriksaan dan mengadili perkara ini sudah tentu harus dapat diputuskan dengan benar oleh suatu "putusan hukum" tentang kebenaran adanya "hak mewaris" dari Penggugat, untuk menentukan kebenaran hal sebagaimana dimaksud dalam di atas sudah tentu diperlukan pemeriksaan dan penetapan kebenarannya melalui sebuah proses pemeriksaan dan pernyataan (putusan) hukum, yang hanya boleh dilakukan oleh Lembaga Pengadilan;

- Bahwa proses pemeriksaan dan pernyataan (putusan) hukum tentang "hak mewaris" yang demikian ini sudah tentu bukan merupakan Jenis Perselisihan Hubungan Industrial, sehingga bukan merupakan kewenangan absolut dari Pengadilan Hubungan Industrial;

- Bahwa satu Pernyataan Penting yang harus dijawab dengan benar dan dapat dipertanggungjawabkan kebenarannya baik secara yuridis maupun secara ilmiah adalah Apakah Pengadilan Hubungan Industrial memiliki Kewenangan untuk memeriksa/mengadili "hak mewaris" dan menyatakan secara deklaratoir dalam amar putusannya bahwa "Seseorang adalah merupakan ahli waris dari almarhum yang meninggal dunia" atau kongkritnya dalam perkara aquo apakah Pengadilan Hubungan Industrial pada Pengadilan Negeri Surabaya berwenang memeriksa dan memutus dengan amar "Menyatakan bahwa Siti Zaenab adalah ahli waris dari Alm Sholehuddin"? apakah Pengadilan Hubungan Industrial berwenang menetapkan hal yang demikian ini? menurut kami hal yang demikian bukan merupakan kewenangan 
Pengadilan Hubungan Industrial, melainkan kewenangan dari lembaga Pengadilan Umum;

- Bahwa berdasarkan hal tersebut maka gugatan Penggugat dalam perkara ini haruslah ditolak atau setidak-tidaknya dinyatakan tidak dapat diterima;

- Eksepsi Tentang Gugatan Tidak Lengkap Dan Tidak Memenuhi Syarat Formal;

- Bahwa tuntutan dalam petitum gugatan angka (2) dan angka (3) tidak didasari dengan adanya uraian penjelasan yang menguraikan alasan-alasan hukum yang mendasari tuntutan tersebut;

- Bahwa tuntutan dalam petitum angka 4 tidak memberikan penjelasan diberikan kepada siapa pembayaran sejumlah uang tersebut;

- Bahwa jika harus dibayar kepada Penggugat, didasarkan pada alasan dan dasar hukum apa? Karena seharusnya amar putusan hukum harus tersusun secara rinci, jelas, tegas dan sistematis sehingga memberikan pedoman alas hak yang benar dan tidak kabur (membingungkan);

- Bahwa oleh karenanya jika harus diputuskan maka amar putusan dalam perkara aquo seharusnya runtut menjelaskan dan menyatakan terlebih dahulu apa status dari Penggugat, apa hubungan hukum antara Penggugat, almarhum Sholehuddin dan Tergugat;

- Bahwa dalam perkara ini Penggugat tidak menuntut agar Pengadilan menyatakan dirinya adalah "pewaris syah" dari almarhum Sholehuddin, hal ini jelas dapat diketahui dengan tidak adanya tuntutan demikian ini dalam petitum gugatan;

- Bahwa adalah merupakan Prinsip Hukum jika suatu putusan hukum dari lembaga Pengadilan haruslah mengandung unsur "kepastian hukum" yang jelas, sehingga dengan tidak dituntutkannya "keabsahan status ahli waris syah atas diri Penggugat terhadap Almarhum Sholehuddin" dan tidak dijelaskannya secara tegas kepada Siapa sejumlah uang yang harus dibayar oleh Tergugat, maka jelas gugatan yang demikian ini adalah tidak jelas, kabur dan membingungkan, sehingga tidak memenuhi syarat formal gugatan yang baik;

- Eksepsi Tentang Gugatan Bersifat Nebis dan Tidak Memiliki Alas Hak dengan alasan bahwa persoalan pokok dalam perkara ini telah diselesaikan dan tuntas melalui kesepakatan/persetujuan antara Penggugat dengan Tergugat;

- Dalam Pokok Perkara Tergugat mengajukan gugatan rekonvensi

- Dalam konvensi : Tergugat telah menyerahkan sejumlah uang yang merupakan kewajiban perusahaan yang harus diberikan kepada "ahli waris" sebagaimana yang diatur dalam ketentuan pasal 166 Undang-Undang Nomor 13 Tahun 2003 telah dilakukan/diselesaikan dengan baik melalui kesepakatan/persetujuan antara Penggugat dengan manajemen perusahaan Tergugat, dengan demikian maka hal yang menjadi persoalan pokok dalam perkara ini telah benar-benar selesai dan tuntas;

- Dalam Rekonvensi Tergugat menuntut ganti kerugian sejumlah Rp. 500.000.000,- karena akibat gugatan Penggugat, Tergugat terpaksa mengeluarkan biaya. 


\section{Alat Bukti}

\section{a. Bukti Penggugat}

1 Fotocopy Surat Anjuran Dinas Tenaga Kerja dan Transmigrasi Kabupaten Mojokerto Nomor : 565/443/416.105/2014 tertanggal 17 April 2014, yang selanjutnya diberi tanda Bukti P-1;

2 Fotocopy Kartu Tanda Penduduk atas nama Sholehuddin, yang selanjutnya diberi tanda Bukti P-2;

3 Fotocopy Kartu Tanda Penduduk atas nama Siti Zaenab, yang selanjutnya diberi tanda Bukti P-3;

4 Fotocopy Kutipan Akta Nikah Sdr.Sholehuddin (alm) dengan Siti Zaenab (ahli waris) tertanggal 10-9-1990, yang selanjutnya diberi tanda Bukti P-4;

5 Fotocopy Kartu Keluarga Nomor : 3516051612020642 atas nama sdr. Sholehuddin (alm) dan Siti Zaenab (istri), yang selanjutnya diberi tanda Bukti P-5;

6Fotocopy Surat Keterangan Ahli Waris Nomor : 470/1205/416.311.8/XII/ 2013 tertanggal 9 Desember 2013, yang selanjutnya diberi tanda Bukti P-6;

7 Fotocopy Surat Jamsostek untuk Pembayaran JHT dan JKM, yang selanjutnya diberi tanda Bukti P-7;

8 Fotocopy Rincian Saldo Jaminan Hari Tua Sholehuddin (alm) untuk masa kerja, yang selanjutnya diberi tanda Bukti P-8;

9 Dua orang saksi yang bernama Siti Fatimah dan Dwi Budiantoro

\section{b. Bukti Tergugat}

Fotocopy Bukti Kas Keluar PT. Prospek Manunggal Era Industri, yang selanjutnya diberi tanda Bukti T-1;

\section{Pertimbangan Hakim}

\section{a. Hakim PHI pada PN. Surabaya}

TENTANG PERTIMBANGAN HUKUM

\section{DALAM KONPENSI :}

\section{DALAM EKSEPSI :}

Menimbang, bahwa Tergugat dalam jawabannya telah mengajukan eksepsi;

Menimbang, bahwa sebelum masuk dalam pokok perkara Majelis Hakim akan mempertimbangkan eksepsi Tergugat terlebih dahulu;

Menimbang, bahwa arti Eksepsi menurut Hukum Acara Perdata adalah tangkisan atau bantahan yang diajukan oleh Tergugat yang tidak menyangkut materi pokok perkara, namun tangkisan atau bantahan yang diajukan dalam bentuk Eksepsi harus dilakukan berdasarkan ketentuan pasal 125 ayat (2), pasal 133, pasal 134 HIR dan pasal 136 $\mathrm{HIR} /$ pasal $162 \mathrm{RBg}$;

Menimbang, bahwa Tergugat dalam jawabannya telah mengajukan eksepsi, yang pada pokoknya sebagai berikut :

1 Eksepsi Kewenangan Absolut Pengadilan Hubungan Industrial yakni Penggugat adalah ahli waris pekerja almarhum Sholehuddin sehingga perselisihan antara 
Penggugat dan Tergugat adalah perselisihan hubungan kewarisan bukan hubungan kerja yang merupakan kewenangan Pengadilan Hubungan Industrial dan Pengadilan Hubungan Industrial tidak berwenang memeriksa dan mengadili Hak Mewaris;

2 Eksepsi Gugatan Tidak Lengkap dan Tidak Memenuhi Syarat Formal yakni petitum angka 2 dan angka 3 tidak ada alasan hukumnya dan petitum angka 4 tidak diberikan penjelasan kepada siapa pembayaran sejumlah uang itu harus dibayarkan sehingga gugatan Penggugat tidak lengkap dan kabur;

3 Eksepsi Gugatan bersifat nebis in idem dan tidak memiliki alas hak yakni posita angka (5), angka (6) dan angka (7) telah jelas dapat diketahui bahwa persoalan pokok dalam perkara ini telah diselesaikan dan tuntas melalui kesepakatan/persetujuan antara Penggugat dengan Tergugat sehingga tidak ada "alas hak" yang mendasari gugatan ini;

Menimbang, bahwa Penggugat telah membantah eksepsi Tergugat dalam replik Penggugat sebagai berikut :

1 Gugatan Penggugat sesuai ketentuan pasal 166 jo. pasal 61 angka 5 Undang-Undang Nomor 13 Tahun 2003 tentang Ketenagakerjaan adalah hak ahli waris pekerja Almarhum Sholehuddin yang merupakan pekerja/ buruh Tergugat bukan tentang hubungan kerja antara Penggugat dan Tergugat ;

2 Gugatan Penggugat disusun secara cermat berdasarkan peristiwa hukum dan dasar hukum yang tepat serta pembayarannya diberikan kepada Penggugat sebagai ahli waris pekerja/buruh Almarhum Sholehuddin;

3 Kwitansi yang ditandatangani Penggugat adalah bukti pembayaran bukan bukti adanya kesepakatan/persetujuan tentang hak pekerja/buruh Almarhum Sholehuddin maka gugatan Penggugat memiliki alas hak yang tepat; ---------

Menimbang, bahwa terhadap eksepsi Tergugat tentang kewenangan absolut Pengadilan Hubungan Industrial pada Pengadilan Negeri Surabaya dalam perkara ini telah diputuskan dalam persidangan Pengadilan Hubungan Industrial pada Pengadilan Negeri Surabaya pada tanggal 8 Oktober 2014 dengan amar putusan sebagai berikut :

1. Menolak eksepsi Tergugat tentang kewenangan absolut;

2. Menyatakan Pengadilan Hubungan Industrial pada Pengadilan Negeri Surabaya berwenang untuk memeriksa dan mengadili perkara ini;

3. Memerintahkan Penggugat dan Tergugat untuk melanjutkan pemeriksaan perkara ini;

4. Menangguhkan biaya perkara dalam perkara ini sampai putusan akhir;

Menimbang, bahwa terhadap eksepsi Tergugat tentang Gugatan Penggugat Tidak Lengkap dan Tidak Memenuhi Syarat Formal serta Gugatan Penggugat bersifat nebis in idem dan tidak memiliki alas hak maka Majelis Hakim berpendapat sebagai berikut :

1 Posita dan petitum gugatan Penggugat adalah perselisihan pemutusan hubungan kerja karena pekerja/buruh Almarhum Sholehuddin meninggal dunia sesuai ketentuan pasal 166 Undang-Undang Nomor 13 Tahun 2003 tentang Ketenagakerjaan sedangkan Penggugat apakah sebagai ahli waris pekerja/buruh Almarhum Sholehuddin adalah 
memerlukan pembuktian dan telah masuk dalam pokok perkara maka eksepsi Tergugat bahwa gugatan Penggugat tidak lengkap dan tidak memenuhi syarat formal dinyatakan ditolak;

2 Gugatan Penggugat adalah perselisihan pemutusan hubungan kerja sesuai ketentuan pasal 166 Undang-Undang Nomor 13 Tahun 2003 karena pekerja/buruh Almarhum Sholehuddin meninggal dunia sedangkan eksepsi Tergugat bahwa persoalan pokok pembayaran hak pekerja/buruh Almarhum Sholehuddin telah diselesaikan dan tuntas melalui kesepakatan/persetujuan antara Penggugat dengan Tergugat sehingga tidak ada "alas hak" yang mendasari gugatan ini adalah telah masuk dalam pokok perkara dan memerlukan pembuktian dengan demikian eksepsi Tergugat bahwa gugatan Penggugat nebis in idem dinyatakan ditolak;

Menimbang, bahwa berdasarkan pertimbangan-pertimbangan tersebut di atas maka eksepsi Tergugat dinyatakan ditolak untuk seluruhnya;

\section{DALAM POKOK PERKARA :}

Menimbang, bahwa maksud dan tujuan Penggugat adalah sebagaimana diuraikan diatas;

Menimbang, bahwa gugatan Penggugat pada pokoknya adalah Penggugat sebagai ahli waris Almarhum Sholehuddin yang meninggal dunia pada tanggal 2 Desember 2013 maka perselisihan pemutusan hubungan kerja antara Penggugat dan Tergugat adalah sesuai ketentuan pasal 166 jo. pasal 61 angka 5 Undang-Undang Nomor 13 Tahun 2003 tentang Ketenagakerjaan;

Menimbang, bahwa terhadap perselisihan tersebut telah dilakukan perundingan bipartit namun tidak menghasilkan kesepakatan;

Menimbang, bahwa oleh karena tidak ada kesepakatan dalam bipartit maka perselisihan dilakukan melalui mediasi oleh Mediator Hubungan Industrial Dinas Tenaga Kerja dan Transmigrasi Kabupaten Mojokerto sesuai Anjuran Mediator Nomor : 565/443/416.105/2014 tertanggal 17 April 2014;

Menimbang, bahwa oleh karena isi anjuran ditolak Tergugat, maka Penggugat mengajukan gugatan ke Pengadilan Hubungan Industrial pada Pengadilan Negeri Surabaya pada tanggal 14 Juli 2014 dengan register perkara Nomor : 74/G/2014/PHI.Sby. sesuai ketentuan pasal 14 ayat 2 Undang-Undang Nomor 2 Tahun 2004 tentang Penyelesaian Perselisihan Hubungan Industrial; -

Menimbang, bahwa dalam gugatan Penggugat pada pokoknya menuntut agar mengabulkan gugatan Penggugat untuk seluruhnya, menyatakan hubungan kerja antara Tergugat dengan almarhum Sholehuddin putus karena pekerja meninggal dunia dengan menerima sejumlah uang sebagaimana ketentuan pasal 166 Undang-Undang Nomor 13 Tahun 2003 tentang Ketenagakerjaan, menyatakan Tergugat telah melakukan perbuatan yang bertentangan dengan Undang-Undang Nomor 2 Tahun 2004 tentang Penyelesaian Perselisihan Hubungan Industrial, menghukum Tergugat untuk membayar kekurangan "sejumlah uang" secara tunai dan sekaligus sebesar Rp.25.793.000,- (dua puluh lima juta tujuh ratus sembilan puluh tiga ribu rupiah) dengan perincian (Rp.45.793.000,- - 
Rp.20.000.000,- = Rp.25.793.000,-) dan menyatakan putusan ini dapat dijalankan terlebih dahulu walaupun ada upaya kasasi;

Menimbang, bahwa gugatan Penggugat pada pokoknya adalah Penggugat sebagai ahli waris Almarhum Sholehuddin yang meninggal dunia pada tanggal 2 Desember 2013 sedangkan Almarhum Sholehuddin adalah pekerja/buruh Tergugat maka perselisihan pemutusan hubungan kerja antara Penggugat dan Tergugat adalah sesuai ketentuan pasal 166 jo. pasal 61 angka 5 Undang-Undang Nomor 13 Tahun 2003 tentang Ketenagakerjaan dan Penggugat telah menerima uang santunan dari Tergugat pada tanggal 7 Desember 2013 sebesar Rp.20.000.000,- (dua puluh juta rupiah);

Menimbang, bahwa terhadap dalil gugatan tersebut, Tergugat telah membantah dalam jawabannya yang pada pokoknya Tergugat telah memberikan hak pemutusan hubungan kerja sesuai ketentuan pasal 166 Undang-Undang Nomor 13 Tahun 2003 pada tanggal 7 April 2014 sebesar Rp. 20.000.000,- (dua puluh juta rupiah) kepada Siti Zaenab selaku ahli waris pekerja/buruh Almarhum Sholehuddin melalui kesepakatan/persetujuan Penggugat dengan Tergugat maka persoalan pokok perkara ini telah diselesaikan dengan tuntas;

Menimbang, bahwa oleh karena dalil gugatan Penggugat telah dibantah kebenarannya oleh Tergugat, maka terhadap perkara ini Penggugatlah yang dibebani kewajiban untuk terlebih dahulu membuktikan kebenaran dalilnya;

Menimbang, bahwa untuk membuktikan dalil-dalil gugatannya, Penggugat telah mengajukan bukti-bukti surat yang diberi tanda P-1 sampai dengan P-8 dan bukti saksi yang bernama Siti Fatimah dan Dwi Budiantoro. Sedangkan sebaliknya Tergugat untuk meneguhkan dalil penyangkalannya telah pula mengajukan bukti surat yang diberi tanda T1 ;

Menimbang, bahwa berdasarkan ketentuan pasal 100 Undang-Undang Nomor 2 Tahun 2004 tentang Penyelesaian Perselisihan Hubungan Industrial menentukan dalam mengambil putusan, Majelis Hakim mempertimbangkan hukum, perjanjian yang ada, kebiasaan, dan keadilan;

Menimbang, bahwa untuk selanjutnya Majelis Hakim akan menilai dan mempertimbangkan secara seksama bukti-bukti yang telah diajukan oleh Penggugat, juga bukti-bukti yang diajukan oleh Tergugat untuk menguatkan dalil bantahannya;

Menimbang, bahwa dalam dalil gugatan Penggugat mendalilkan Penggugat adalah ahli waris Almarhum Sholehuddin yang bekerja pada Tergugat sejak bulan Desember 2001 dan Almarhum Sholehuddin meninggal dunia pada tanggal 2 Desember 2013 maka Majelis Hakim berpendapat perselisihan antara Penggugat dan Tergugat adalah perselisihan pemutusan hubungan kerja antara Penggugat sebagai ahli waris pekerja/buruh Almarhum Sholehuddin pada perusahaan Tergugat sesuai ketentuan pasal 1 angka 14 dan pasal 1 angka 15 jo. pasal 166 Undang-Undang Nomor 13 Tahun 2003 tentang Ketenagakerjaan;

Menimbang, bahwa dalam dalil gugatan Penggugat mendalilkan perselisihan antara Penggugat dan Tergugat adalah perselisihan pemutusan hubungan kerja disebabkan 
pekerja/buruh Tergugat yang bernama Almarhum Sholehuddin meninggal dunia dan Almarhum Sholehuddin bekerja pada Tergugat sejak bulan Desember 2001 dengan upah terakhir perbulan sebesar Rp.1.740.000,- (satu juta tujuh ratus empat puluh ribu rupiah);

Menimbang, bahwa berdasarkan bukti surat Penggugat yang diberi tanda P-1 yakni Surat Anjuran Dinas Tenaga Kerja dan Transmigrasi Kabupaten Mojokerto Nomor : 565/443/416.105/2014 tertanggal 17 April 2014 menerangkan sebagai berikut :

- Almarhum Sholehuddin adalah karyawan pada bagian security/satpam yang meninggal dunia pada tanggal 2 Desember 2013 karena sakit;

- Almarhum Sholehuddin meninggalkan seorang istri yang bernama Siti Zaenab dan anaknya yang bernama Dian Fatmawati;

- Perusahaan telah memberikan uang pada ahli warisnya yang bernama Ibu Siti Zaenab sebesar Rp.20.000.000,- (dua puluh juta rupiah) pada tanggal 7 Desember 2013 dengan bukti kwitansi penerimaan;

- Ibu Siti Zaenab berpendapat uang sebesar Rp.20.000.000,- (dua puluh juta rupiah) pada tanggal 7 Desember 2013 adalah uang santunan sedangkan perusahaan berpendapat telah membayar hak-hak Almarhum Sholehuddin kepada ahli warisnya;

Anjuran Mediator Hubungan Industrial adalah sebagai berikut : Agar pihak pengusaha (PT. Prospek M.E.I) dan Sdri. Siti Zaenab selaku ahli waris pekerja Almarhum Sholehuddin dalam melakukan penyelesaian pesangon serta hak-hak lainnya Almarhum Sholehuddin sebagaimana bukti penerimaan Nomor : BKK 43/XII/2013 tanggal 5 Desember 2013 dituangkan dalam Perjanjian Bersama yang ditandatangani oleh kedua belah pihak;

Menimbang, bahwa berdasarakan bukti surat Penggugat yang diberi tanda P-2 yakni Kartu Tanda Penduduk atas nama Sholehuddin menerangkan Sholehuddin, tempat/tanggal lahir : Mojokerto, 7 April 1969, alamat : Dusun Manduro MG RT/RW. 001/001 Kelurahan/Desa : Manduro MG Kecamatan Ngoro Mojokerto, Agama : Islam, status perkawinan : kawin;

Menimbang, bahwa berdasarakan bukti surat Penggugat yang diberi tanda P-3 yakni Kartu Tanda Penduduk atas nama Siti Zaenab menerangkan Siti Zaenab, tempat/tanggal lahir : Kediri, 25 Agustus 1967, alamat : Dusun Manduro MG RT/RW. 001/001 Kelurahan/Desa : Manduro MG Kecamatan Ngoro Mojokerto, Agama : Islam, status perkawinan : kawin;

Menimbang, bahwa berdasarakan bukti surat Penggugat yang diberi tanda P-4 yakni Kutipan Akta Nikah Sdr. Sholehuddin (Almarhum) dengan Siti Zaenab (ahli waris) tertanggal 10-9-1990 menerangkan pekerja/buruh Sdr. Sholehuddin (Almarhum) menikah dengan Siti Zaenab (ahli waris) tertanggal 10-9-1990;

Menimbang, bahwa berdasarakan bukti surat Penggugat yang diberi tanda P-5 yakni Kartu Keluarga Nomor : 3516051612020642 sdr. Sholehuddin (Almarhum) dan Siti Zaenab (istri) menerangkan Kartu Keluarga dengan Kepala Keluarga Sholehuddin, 
beralamat Dusun Manduro MG RT/RW. 001/001 Kelurahan/Desa : Manduro MG Kecamatan Ngoro Kabupaten Mojokerto;

Menimbang, bahwa berdasarakan bukti surat Penggugat yang diberi tanda P-6 yakni Surat Keterangan Ahli Waris Nomor : 470/1205/416.311.8/XII/2013 tertanggal 9 Desember 2013 dari Kepala Desa Manduro Manggung Gajah Kecamatan Ngoro Kabupaten Mojokerto menerangkan;

Nama : Siti Zaenab ;

Tempat/Tanggal lahir : Kediri, 25 Agustus 1967 ;

Agama : Islam ;

Alamat : Dusun Manduro MG RT/RW. 001/001, Kelurahan/Desa : Manduro MG, Kec. Ngoro Kab. Mojokerto ;

Menerangkan : bahwa orang tersebut di atas adalah benar-benar ahli waris/istri dari almarhum Sholehuddin yang meninggal dunia pada tanggal 2 Desember 2013;

Menimbang, bahwa berdasarakan bukti surat Penggugat yang diberi tanda P-7 yakni Surat Jamsostek untuk Pembayaran JHT dan JKM tertanggal 13 Desember 2013 menerangkan uang JHT dan JKM untuk Siti Zaenab sebesar Rp. 27.602.520,-;

Menimbang, bahwa berdasarakan bukti surat Penggugat yang diberi tanda P-8 yakni Rincian Saldo Jaminan Hari Tua Sholehuddin (almarhum) untuk masa kerja menerangkan Almarhum Sholehuddin bekerja pada Tergugat sejak bulan Desember 2001;

Menimbang, bahwa berdasarkan bukti surat Tergugat yang diberi tanda T-1 yakni Bukti Kas Keluar PT.Prospek Manunggal Era Industri Nomor : BKK 43/XII/13 tertanggal 5 Desember 2013 menerangkan "Dana santunan kematian Almarhum Sholehuddin (security) dan penyelesaian pesangon serta hak-hak lainnya serta para pihak tidak akan melakukan tuntutan perdata, pidana maupun tuntutan hubungan kerja sebesar Rp. 20.000.000,- (dua puluh juta rupiah);

Menimbang, bahwa berdasarkan ketentuan Undang-Undang Nomor 13 Tahun 2003 tentang Ketenagakerjaan menentukan sebagai berikut : Pasal 166 "Dalam hal hubungan kerja berakhir karena pekerja/buruh meninggal dunia, kepada ahli warisnya diberikan sejumlah uang yang besar perhitungannya sama dengan perhitungan 2 (dua) kali uang pesangon sesuai ketentuan pasal 156 ayat (2), 1 (satu) kali uang penghargaan masa kerja sesuai ketentuan pasal 156 ayat (3) dan uang penggantian hak sesuai ketentuan pasal 156 ayat (4);

Menimbang, bahwa berdasarkan pertimbangan dan ketentuan tersebut di atas maka Majelis Hakim berpendapat perselisihan antara Penggugat dan Tergugat adalah perselisihan pemutusan hubungan kerja karena pekerja/buruh Almarhum Sholehuddin meninggal dunia pada tanggal 2 Desember 2013 dan berdasarkan bukti surat P-1, P-3, P-4, P-5, P-6, P-7, P-8 menerangkan Siti Zaenab adalah ahli waris Almarhum Sholehuddin yang merupakan pekerja/buruh Tergugat dengan demikian Penggugat memenuhi ketentuan pasal 166 Undang-Undang Nomor 13 Tahun 2003 dan hubungan kerja antara Tergugat dengan 
Almarhum Sholehuddin dinyatakan putus sejak tanggal 2 Desember 2013 serta petitum gugatan Penggugat angka 2 dinyatakan dikabulkan;

Menimbang, bahwa berdasarkan bukti surat P-1 maka Majelis Hakim berpendapat oleh karena tidak ada bukti permohonan perjanjian bersama dan kesepakatan antara Penggugat dan Tergugat untuk pembayaran hak pemutusan hubungan kerja karena meninggal dunianya pekerja yakni Almarhum Sholehuddin dengan demikian petitum gugatan Penggugat angka 3 dinyatakan dikabulkan;

Menimbang, bahwa oleh karena Almarhum Sholehuddin meninggal dunia pada tanggal 2 Desember 2013 sedangkan Almarhum Sholehuddin bekerja pada Tergugat sejak bulan Desember 2001 dengan upah terakhir perbulan sebesar Rp. 1.740.000,- (satu juta tujuh ratus empat puluh ribu rupiah) sebagaimana keterangan saksi Penggugat yang bernama Siti Fatimah dan Dwi Budiantoro yang menerangkan Almarhum Sholehuddin meninggal dunia dan menerima upah terakhir perbulan sebesar Rp.1.740.000,- (satu juta tujuh ratus empat puluh ribu rupiah) dengan masa kerja +12 tahun maka Majelis Hakim berpendapat masa kerja Almarhum Sholehuddin adalah 12 tahun dengan upah terakhir perbulan sebesar Rp. 1.740.000,- (satu juta tujuh ratus empat puluh ribu rupiah) dan hak pemutusan hubungan kerja Almarhum Sholehuddin sesuai ketentuan pasal 166 UndangUndang Nomor 13 Tahun 2003 sebesar sebagai berikut :

- Uang pesangon : 9 × 2 x Rp.1.740.000,- = Rp. 31.320.000,-

- Uang penghargaan masa kerja : $5 \times$ Rp.1.740.000,- $=\mathrm{Rp} .8 .700 .000,-$

- Uang penggantian hak: $15 \% \times$ Rp.40.020.000,- $=\underline{\text { Rp. } 6.003 .000_{--}+}$

Total : $=$ Rp. 46.023.000,-

Menimbang, bahwa oleh karena Tergugat telah memberi uang kepada Penggugat sebagai ahli waris Almarhum Solehuddin pada tanggal 7 Desember 2013 sebesar Rp. 20.000.000,- (dua puluh juta rupiah) sesuai dengan bukti surat Penggugat yang diberi tanda P-1 dan bukti surat Tergugat yang diberi tanda T-1 maka Majelis Hakim berpendapat hak pemutusan hubungan kerja yang wajib dibayar Tergugat kepada Almarhum Sholehuddin adalah sebesar Rp. 46.023.000,- - Rp. 20.000.000,- = Rp. 26.023.000,- (dua puluh enam juta dua puluh tiga ribu rupiah) sehingga petitum gugatan Penggugat angka 4 dinyatakan dikabulkan;

Menimbang, bahwa berdasarkan ketentuan pasal 180 ayat (1) HIR maka Majelis Hakim berpendapat petitum gugatan Penggugat agar putusan dapat dijalankan terlebih dahulu walaupun ada upaya kasasi oleh Tergugat dinyatakan ditolak;

Menimbang, bahwa terhadap bukti-bukti yang tidak dipertimbangkan secara satupersatu telah dianggap dan menjadi pertimbangan dalam putusan ini;

Menimbang, bahwa berdasarkan pertimbangan tersebut diatas, maka gugatan Penggugat dikabulkan untuk sebagian;

DALAM REKONPENSI :

Menimbang, bahwa Tergugat dalam jawabannya telah mengajukan gugatan rekonpensi; 
Menimbang, bahwa maksud dan tujuan gugatan rekonpensi dari Penggugat Rekonpensi adalah sebagaimana tersebut diatas;

Menimbang, bahwa Penggugat Rekonpensi dalam gugatannya menuntut agar menghukum Tergugat Rekonpensi untuk membayar secara tunai dan seketika kepada Penggugat Rekonpensi sebagai ganti rugi sejumlah Rp. 500.000.000,- (lima ratus juta rupiah);

Menimbang, bahwa dalam gugatan rekonpensi Penggugat Rekonpensi mendalilkan bahwa Tergugat Rekonpensi telah merugikan Penggugat Rekonpensi secara materiil dan inmateriil yakni kerugian waktu, nama baik dan biaya operasional Advokat sebesar Rp. 500.000.000,- (lima ratus juta rupiah);

Menimbang, bahwa dalam repliknya Tergugat Rekonpensi menyangkal dalil Penggugat Rekonpensi dengan menerangkan bahwa Tergugat Rekonpensi telah melakukan upaya perundingan bipartit namun tidak ada kesepakatan dengan Penggugat Rekonpensi;

Menimbang, bahwa hal-hal yang berkaitan dengan pertimbangan dan penilaian hukum dalam konpensi maka secara mutatis muntandis berlaku dan menjadi satu kesatuan dengan pertimbangan dan penilaian hukum dalam gugatan rekonpensi ini;

Menimbang, bahwa dalam gugatan rekonpensi ini baik Penggugat Rekonpensi maupun Tergugat Rekonpensi tidaklah mengajukan bukti-bukti tersendiri melainkan mempergunakan pula bukti-bukti yang diajukan dalam gugatan konpensi;

Menimbang, bahwa oleh karena gugatan Penggugat Konpensi adalah perselisihan pemutusan hubungan kerja sesuai ketentuan pasal 166 Undang-Undang Nomor 13 Tahun 2003 yang telah dipertimbangkan dalam pokok perkara konpensi sedangkan gugatan Penggugat Rekonpensi tentang kerugian materiil dan inmateriil yang tidak diatur dalam ketentuan Undang-Undang Nomor 13 Tahun 2003 dan Undang-Undang Nomor 2 Tahun 2004 serta bukanlah kewenangan Pengadilan Hubungan Industrial pada Pengadilan Negeri Surabaya untuk memeriksa dan mengadili perselisihan kerugian materiil dan inmateriil maka petitum gugatan Penggugat Rekonpensi dinyatakan ditolak;

Menimbang, bahwa terhadap bukti-bukti yang tidak dipertimbangkan secara satupersatu telah dianggap dan menjadi pertimbangan dalam putusan ini;

Menimbang, bahwa berdasarkan pertimbangan tersebut diatas, maka gugatan Penggugat Rekonpensi ditolak untuk seluruhnya;

DALAM KONPENSI DAN REKONPENSI :

Menimbang, bahwa oleh karena gugatan Penggugat Konpensi dikabulkan untuk sebagian dan gugatan Penggugat Rekonpensi ditolak untuk seluruhnya, maka biaya perkara yang timbul dalam perkara ini ditanggung oleh Tergugat Konpensi/ Penggugat Rekonpensi;

Menimbang, bahwa sesuai ketentuan pasal 58 Undang-Undang Nomor 2 Tahun 2004 ditentukan bahwa pihak-pihak yang berperkara tidak dikenakan biaya yang nilai gugatannya di bawah Rp.150.000.000,- (seratus lima puluh juta rupiah) dan oleh karena nilai gugatan Penggugat di bawah Rp.150.000.000,- (seratus lima puluh juta rupiah), maka 
biaya perkara dalam perkara ini dibebankan kepada Negara sebesar Rp.311.000,- (tiga ratus sebelas ribu rupiah);

Memperhatikan ketentuan Undang-Undang Nomor 13 Tahun 2003 tentang Ketenagakerjaan, Undang-Undang Nomor 2 Tahun 2004 tentang Penyelesaian Perselisihan Hubungan Industrial dan peraturan-peraturan lain yang bersangkutan;

M E N G A D I L I

DALAM KONPENSI :

DALAM EKSEPSI :

- Menolak eksepsi Tergugat seluruhnya;

DALAM POKOK PERKARA :

1 Mengabulkan gugatan Penggugat untuk sebagian;

2 Menyatakan perselisihan pemutusan hubungan kerja antara Penggugat dan Tergugat sesuai ketentuan pasal 166 Undang-Undang Nomor 13 Tahun 2003 tentang Ketenagakerjaan;

3 Menghukum Tergugat membayar hak pemutusan hubungan kerja kepada Penggugat sebesar Rp.46.023.000,- - Rp.20.000.000,- = Rp.26.023.000,- (dua puluh enam juta dua puluh tiga ribu rupiah);

4 Menolak gugatan Penggugat untuk selain dan selebihnya;

DALAM REKONPENSI;

- Menolak gugatan Penggugat Rekonpensi untuk seluruhnya;

DALAM KONPENSI DAN REKONPENSI;

- Membebankan biaya perkara yang timbul dalam perkara ini kepada Negara sebesar Rp.311.000,- (tiga ratus sebelas ribu rupiah);

\section{b. Hakim Agung pada Mahkamah Agung}

Menimbang bahwa keberatan-keberatan tersebut tidak dapat dibenarkan, karena meneliti dengan seksama permohonan kasasi tertanggal 19 November 2014, kontra memori kasasi tertanggal 15 Desember 2014, dihubungkan dengan Putusan Judex Facti dalam hal ini Putusan Pengadilan Hubungan Industrial pada Pengadilan Negeri Surabaya, ternyata Judex Facti tidak salah dan telah benar dalam menerapkan ketentuan Pasal 166 UndangUndang Nomor 13 Tahun 2003, sedangkan uang sejumlah Rp. 20.000.000,00 yang diberikan oleh Tergugat kepada Penggugat terbukti tidak berkaitan dengan hak-hak yang diatur dalam ketentuan Pasal 166 Undang-Undang Nomor 13 Tahun 2003, namun berkaitan dengan santunan kematian;

Menimbang, bahwa berdasarkan pertimbangan di atas, lagi pula ternyata bahwa putusan Judex Facti dalam perkara ini tidak bertentangan dengan hukum dan/atau undangundang, maka permohonan kasasi yang diajukan oleh Pemohon Kasasi PT. Prospek Manunggal Era Industri, tersebut harus ditolak;

Menimbang, bahwa berdasarkan pertimbangan di atas, lagi pula ternyata bahwa putusan Judex Facti dalam perkara ini tidak bertentangan dengan hukum dan/atau undang- 
undang, maka permohonan kasasi yang diajukan oleh Pemohon Kasasi : PT. Prospek Manuggal Era Industri tersebut harus ditolak;

Menimbang, bahwa oleh karena nilai gugatan dalam perkara ini dibawah Rp.150.000.000,00 (seratus lima puluh juta rupiah), maka sesuai dengan ketentuan Pasal 58 Undang-Undang Nomor 2 Tahun 2004 semua biaya perkara dibebankan kepada Negara;

Memperhatikan pasal-pasal dari Undang-Undang Nomor 4 Tahun 2004, UndangUndang Nomor 14 Tahun 1985 sebagaimana yang telah diubah dengan Undang-Undang No 5 Tahun 2004 dan Undang-Undang Nomor 13 Tahun 2003, Undang-Undang Nomor 2 Tahun 2004 serta peraturan perundang-undangan lain yang bersangkutan.

c. Analisis terhadap putusan PHI pada PN. Surabaya dan Mahkamah Agung.

Dalam putusannya, Judex Factie PHI pada PN. Surabaya telah menolak eksepsi Tergugat berkaitan dengan kompetensi absolut dalam sebuah putusan sela. Walaupun putusan sela tersebut tidak tercantum dalam putusan akhir, namun berdasarkan pertimbangan yang termuat dalam putusan akhir, Majelis Hakim menyebut perselisihan antara Penggugat dan Tergugat adalah perselisihan pemutusan hubungan kerja antara Penggugat sebagai ahli waris pekerja/buruh Almarhum Sholehuddin pada perusahaan Tergugat sesuai ketentuan pasal 1 angka 14 dan pasal 1 angka 15 jo. pasal 166 UndangUndang Nomor 13 Tahun 2003 tentang Ketenagakerjaan.

Menurut penulis pencantuman dasar hukum pasal 1 angka 14 dan pasal 1 angka 15 adalah tidak tepat, karena kedua Pasal tersebut berkaitan dengan Perjanjian kerja dan hubungan kerja. Perjanjian kerja adalah perjanjian antara pekerja/buruh dengan pengusaha atau pemberi kerja yang memuat syarat-syarat kerja, hak, dan kewajiban para pihak, sedangkan Hubungan Kerja adalah hubungan antara pengusaha dengan pekerja/buruh berdasarkan perjanjian kerja, yang mempunyai unsur pekerjaan, upah, dan perintah. Sedangkan ketentuan Pasal 1 angka 4 UU PPHI disebutkan bahwa Perselisihan Pemutusan Hubungan Kerja adalah perselisihan yang timbul karena tidak adanya kesesuaian pendapat mengenai pengakhiran hubungan kerja yang dilakukan oleh salah satu pihak.

Menurut penulis pertimbangan yang menyatakan perselisihan adalah perselisihan PHK adalah kurang tepat, karena dengan meninggalnya Sholehuddin (Suami Penggugat) maka telah terjadi PHK demi hukum. Jika merujuk pada ketentuan Pasal 61 ayat (1) UUK yang menyatakan Perjanjian kerja berakhir apabila : a) Pekerja meninggal dunia dan Pasal 61 ayat (5) yang menyatakan "Dalam hal pekerja/buruh meninggal dunia, ahli waris pekerja/buruh berhak mendapatkan hak-haknya sesuai dengan peraturan perundang-undangan yang berlaku atau hak-hak yang telah diatur dalam perjanjian kerja, peraturan perusahaan, atau perjanjian kerja bersama. Hak-hak dimaksud kemudian ditegaskan dalam Pasal 166 UUK yang menyatakan "Dalam hal hubungan kerja berakhir karena pekerja/buruh meninggal dunia, kepada ahli warisnya diberikan sejumlah uang yang besar perhitungannya sama dengan perhitungan 2 (dua) kali uang pesangon sesuai ketentuan Pasal 156 ayat (2), 1 (satu) kali uang penghargaan masa kerja sesuai ketentuan Pasal 156 ayat (3), dan uang penggantian hak sesuai ketentuan Pasal 156 ayat (4). Dalam 
perkara ini jelas bahwa Tergugat menolak memberikan hak-hak ahli waris sesuai ketentuan Pasal 166 UUK karena telah memberi uang santunan sejumlah Rp. 20.000.000,- (duapuluh juta) kepada Penggugat. Sedangkan Penggugat menuntut agar haknya diberikan/dipenuhi sesuai ketentuan Pasal 166. Terdapat perbedaan pelaksanaan/penafsiran antara Penggugat dan Tergugat terhadap ketentuan peraturan perundang-undangan berkaitan dengan hak ahli waris pekerja yang meninggal. Seharusnya perselisihan perkara antara Penggugat dan Tergugat adalah merupakan perselisihan hak sebagaimana ketentuan Pasal 1 angka 2 UU PPHI yang menyatakan "Perselisihan hak adalah perselisihan yang timbul karena tidak dipenuhinya hak, akibat adanya perbedaan pelaksanaan atau penafsiran terhadap ketentuan peraturan perundang-undangan, perjanjian kerja, peraturan perusahaan, atau perjanjian kerja bersama". Oleh karena itu maka Pengadilan Hubungan Industrial pada Pengadilan Negeri Surabaya berwenang (memiliki kompetensi absolut) mengadili perkara antara Penggugat dan Tergugat.

Selanjutnya, pertimbangan Judex Factie yang menolak eksepsi Tergugat lainnya dengan alasan sudah masuk ke dalam pokok perkara adalah sudah tepat karena untuk menentukan apakah ada hubungan hukum antara Penggugat dan Tergugat, apakah Penggugat adalah ahli waris dari Alm. Sholehuddin dan apakah perselisihan ini sudah tuntas sebelumnya maka harus diperiksa di dalam pokok perkara yaitu memeriksa buktibukti dan saksi.

Majelis hakim dalam menentukan apakah benar Sholehuddin (alm) sebagai pekerja Tergugat yang telah bekerja selama 12 tahun dengan gaji terakhir sejumlah Rp. 1.700.000,, apakah Penggugat memiliki hubungan hukum dengan Tergugat dan apakah Penggugat adalah ahli waris Alm. Sholehuddin yang merupakan pekerja yang bekerja pada Tergugat berdasarkan bukti P-1, P-3, P-4, P-5, P-6, P-7, P-8, bukti T.1 dan keterangan 2 orang saksi adalah sudah tepat. Namun menurut penulis, pertimbangan tersebut bisa diperkuat lagi dengan menambahkan dasar hukum lainnya. Mengingat Tergugat di dalam Eksepsi dan Jawabannya mempertanyakan kebenaran Penggugat sebagai ahli waris dari Sholehuddin (alm), menurut penulis pertimbangan bagian ini perlu ditambah landasan yuridisnya yaitu dengan menambahkan dasar hukum kewenangan kepala Desa mengeluarkan surat Surat Keterangan Ahli Waris. Majelis hakim juga bisa menambahkan alat bukti persangkaan sebagaimana ketentuan Pasal 173 HIR. Hakim bisa menilai dengan dibayarkannya uang santunan oleh Tergugat kepada Penggugat sejumlah Rp. 20.000.000,- di rumah Penggugat adalah merupakan pengakuan Tergugat bahwa Penggugat adalah ahli waris sah dari Sholehuddin (alm). Disamping itu majelis hakim juga bisa melakukan persangkaan menurut aturan perundang-undangan dengan melihat ketentuan kompilasi hukum Islam mengingat Penggugat dan Sholehuddin (alm) adalah beragama Islam. Dengan menambahkan tidak adanya sengketa waris antara Penggugat dengan pihak lain, maka semakin kuat persangkaan bahwa Penggugat adalah ahli waris dari Sholehuddin (alm). Dengan jelasnya Penggugat sebagai ahli waris Sholehuddin, maka Penggugat memiliki hubungan hukum dengan Tergugat berdasarkan ketentuan Pasal 61 ayat (5) dan Pasal 166 
UUK yaitu sebagai ahli waris yang seharusnya diberi sejumlah uang sesuai ketentuan Pasal 156 ayat (2), (3) dan (4) UUK.

Penulis melihat kekurangan dari gugatan yang diajukan oleh Penggugat berkaitan dengan dasar hukum Penggugat mengajukan gugatan. Seharusnya gugatan yang diajukan adalah perselisihan hak dengan dasar Pasal 61 ayat (5) UUK, bukan gugatan perselisihan PHK dengan dasar ketentuan Pasal 166 UUK. Disamping itu, dalam pembuktiannya, Penggugat tidak menampilkan bukti surat pengangkatan Sholehuddin (alm) sebagai karyawan Tergugat maupun slip gaji terakhir yang menurut Penulis sangat penting untuk membuktikan dalil-dalil posita gugatan Penggugat.

Judex Factie PHI pada PN. Surabaya tidak tegas memberi pertimbangan kenapa bukti surat Tergugat yang diberi tanda T-1 ditolak, yakni Bukti Kas Keluar PT.Prospek Manunggal Era Industri Nomor : BKK 43/XII/13 tertanggal 5 Desember 2013 menerangkan "Dana santunan kematian Almarhum Sholehuddin (security) dan penyelesaian pesangon serta hak-hak lainnya serta para pihak tidak akan melakukan tuntutan perdata, pidana maupun tuntutan hubungan kerja sebesar Rp. 20.000.000,- (dua puluh juta rupiah), dimana bukti ini didalilkan sebagai bukti telah selesainya hak dan kewajiban antara Penggugat dengan Tergugat.

Dikabulkan Petitum Penggugat senilai Rp. 46.023.000,- - Rp. 20.000.000,- = Rp. 26.023.000,- (dua puluh enam juta dua puluh tiga ribu rupiah) adalah telah sesuai dengan petitum gugatan. Menurut penulis seharusnya tuntutan yang dicantumkan adalah Rp. 46.023.000,-, tidak perlu dikurangi dengan uang senjumlah Rp. 20.000.000,- karena uang sejumlah Rp. 20.000.000,- berupa uang santunan dan bukan merupakan sejumlah uang sebagaimana maksud ketentuan Pasal 166, Pasal 156 ayat [2]. [3] dan [4] UUK. Judex Factie dalam memutus perkara tidak boleh memutus lebih dari yang dituntut. Hal ini diatur dalam Pasal 178 ayat [3] HIR yang menyatakan Hakim tidak diizinkan menjatuhkan keputusan atas perkara yang tidak digugat, atau memberikan lebih dari pada yang digugat. Namun dalam Pasal 178 [1] HIR Hakim karena jabatannya waktu bermusyawarah wajib mencukupkan segala alasan hukum yang tidak dikemukakan oleh kedua belah pihak. Menurut Penulis Judex Factie bisa saja mengabulkan sejumlah uang sebagaimana ketentuan Pasal 166, Pasal 156 ayat [2]. [3] dan [4] UUK yaitu sejumlah Rp. 46.023.000,karena berdasarkan Bukti T-1 uang Rp. 20.000.000,- adalah merupakan uang santunan kematian. Bukti T.1 bukan pula merupakan sebagia bukti Perjanjian Bersama dalam penyelesaian perselisihan sebagaimana disyaratkan oleh UU PPHI. Judex Factie bisa mencantumkan beberapa Yurisprudensi, diantaranya Putusan MARI No. 140 K/Si[/1971 yang menyatakan Hakim dibenarkan membuat putusan bersifat ultra petita dengan syarat harus masih dalam kerangka yang serasi dengan inti gugatan. Putusan yang "ultra petita" [memutus lebih dari yang dituntut] dimungkin pula karena Penggugat dalam bagian akhir gugatannya juga menuntut tuntutan Subsidair yang meminta putusan yang seadil-adilnya.

Pada tingkat kasasi, Judex Juris menolak kasasi dari Tergugat, hal ini sudah tepat. Di dalam Pertimbangannya, Judex Juris menambahkan alasan berkaitan dengan Bukti T-1 
dengan menyatakan uang sejumlah Rp. 20.000.000,00 yang diberikan oleh Tergugat kepada Penggugat terbukti tidak berkaitan dengan hak-hak yang diatur dalam ketentuan Pasal 166 Undang-Undang Nomor 13 Tahun 2003, namun berkaitan dengan santunan kematian. Menurut Penulis, pertimbangan hukum tersebut bisa diperkuat lagi dengan menyatakan bahwa bukti T-1 bukanlah merupakan produk Perjanjian Bersama sebagaimana yang disyaratkan oleh Pasal 7 ayat (1), (2), (3) dan (4) UU PPHI. Dengan adanya pertimbangan Judex Juris, maka dari itu semakin kuat untuk mengabulkan hak Penggugat atas sejumlah uang sesuai dengan Pasal 166, Pasal 156 ayat [2]. [3] dan [4] UUK yaitu sejumlah Rp. 46.023.000,- tanpa dikurangi uang sejumlah Rp. 20.000.000,yang telah diberikan Tergugat karena hanya berupa uang santunan.

\section{KESIMPULAN}

Dalam KUHPPerdata pemutusan kerja yang terjadi dengan sendirinya yakni ketika pekerja meninggal dunia yang diatur dalam ketentuan pasal $1603 \mathrm{j}$ KUPerdata. Selanjutnya dalam ketentuan Pasal 1601 y KUHPerdata juga disebutkan hubungan kerja berakhir dengan meninggalnya seorang pekerja dan jika pekerja meninggal dunia, berakibat PHK demi huku. Namun secara spesifik tidak dijelaskan apa saja dan berapa besaran hak yang diterima ahli waris. Kemudian Pasal 21 ayat (1) UU No. 25 tahun 1997 tentang Ketenagakerjaan yang menyatakan; ayat (1) : Perjanjian kerja berakhir apabila : a. pekerja meninggal dunia. Ayat (4) Dalam hal pekerja meninggal dunia, ahli waris pekerja berhak mendapatkan hak-haknya sesuai dengan peraturan perundang-undangan yang berlaku atau hak-hak yang telah diatur dalam perjanjian kerja, peraturan perusahaan, atau kesepakatan kerja bersama. UU Nomor 25 Tahun 1997 ini tidak jadi diundangkan dan dicabut oleh UUK.

Selanjutnya ketentuan ahli waris pekerja yang meninggal dunia diatur dalam UUK Pasal 61 ayat (1) menyatakan Perjanjian kerja berakhir apabila : a) Pekerja meninggal dunia. Selanjutnya Pasal 61 ayat (5) menyatakan "Dalam hal pekerja/buruh meninggal dunia, ahli waris pekerja/ buruh berhak mendapatkan hak haknya sesuai dengan peraturan perundang-undangan yang berlaku atau hak hak yang telah diatur dalam perjanjian kerja, peraturan perusahaan, atau perjanjian kerja bersama. Ketentuan lebih khusus tentang hak ahli waris pekerja yang meninggal diatur dalam Pasal 166 UUK yang menyatakan "Dalam hal hubungan kerja berakhir karena pekerja/buruh meninggal dunia, kepada ahli warisnya diberikan sejumlah uang yang besar perhitungannya sama dengan perhitungan 2 (dua) kali uang pesangon sesuai ketentuan Pasal 156 ayat (2), 1 (satu) kali uang penghargaan masa kerja sesuai ketentuan Pasal 156 ayat (3), dan uang penggantian hak sesuai ketentuan Pasal 156 ayat (4).

Ketentuan Pasal 166 UUK ini kemudian dihapus dalam UU Ciptaker, namun dihidupkan kembali dalam ketentuan Pasal 57 Peraturan Pemerintah Republik Indonesia (PP) Nomor 35 Tahun 2021 tentang Perjanjian Kerja Waktu Tertentu, Alih daya, Waktu Kerja dan Waktu Istirahat, dan Pemutusan Hubungan Kerja. Ketentuan Pasal 57 PP No. 35 Tahun 2021 menyatakan "Pemutusan Hubungan Kerja karena alasan Pekerja/Buruh meninggal dunia maka kepada ahli warisnya diberikan sejumlah uang yang perhitungannya sama dengan: a. uang 
pesangon Pasal 40 ayat (2), sebesar 2 (dua) kali ketentuan, b. uang penghargaan masa kerja sebesar 1 (satu) kali ketentuan Pasal 40 ayat (3); dan c. uang penggantian hak sesuai ketentuan Pasal 40 ayat (4).

Pertimbangan hakim Judex facti PHI pada PN Surabaya pertimbangan yang menyatakan perselisihan adalah perselisihan PHK adalah kurang tepat, karena dengan meninggalnya Sholehuddin (Suami Penggugat) maka telah terjadi PHK demi hukum, Jika merujuk pada ketentuan Pasal 61 ayat (1) UUK yang menyatakan Perjanjian kerja berakhir apabila : a) Pekerja meninggal dunia dan Pasal 61 ayat (5) yang menyatakan "Dalam hal pekerja/buruh meninggal dunia, ahli waris pekerja/buruh berhak mendapatkan hak-haknya sesuai dengan peraturan perundang-undangan yang berlaku atau hak-hak yang telah diatur dalam perjanjian kerja, peraturan perusahaan, atau perjanjian kerja bersama. Hak-hak dimaksud kemudian ditegaskan dalam Pasal 166 UUK yang menyatakan "Dalam hal hubungan kerja berakhir karena pekerja/buruh meninggal dunia, kepada ahli warisnya diberikan sejumlah uang yang besar perhitungannya sama dengan perhitungan 2 (dua) kali uang pesangon sesuai ketentuan Pasal 156 ayat (2), 1 (satu) kali uang penghargaan masa kerja sesuai ketentuan Pasal 156 ayat (3), dan uang penggantian hak sesuai ketentuan Pasal 156 ayat (4). Seharusnya perselisihan antara Penggugat dan tergugat adalah perselisihan hak.

Pada tingkat kasasi, Judex Juris menolak kasasi dari Tergugat, hal ini sudah tepat. Menurut Penulis, pertimbangan hukum tersebut bisa diperkuat lagi dengan menyatakan bahwa bukti T-1 bukanlah merupakan produk Perjanjian Bersama sebagaimana yang disyaratkan oleh Pasal 7 ayat (1), (2), (3) dan (4) UU PPHI. Dengan adanya pertimbangan Judex Juris, maka dari itu semakin kuat untuk mengabulkan hak Penggugat atas sejumlah uang sesuai dengan Pasal 166, Pasal 156 ayat [2]. [3] dan [4] UUK yaitu sejumlah Rp. 46.023.000,- tanpa dikurangi uang sejumlah Rp. 20.000.000,- yang telah diberikan Tergugat karena hanya berupa uang santunan.

\section{DAFTAR PUSTAKA}

Abdul Khakim, 2014, Dasar-Dasar Hukum Ketenagakerjaan, Bandung, PT Citra Aditya Bakti

Abdul Khakim, 2013, Aspek Hukum Penyelesaian Perselisihan Hubungan Industrial, Bandung, PT Citra Aditya Bakti

Abdul Khakim, 2003, Pengantar Hukum Ketenagakerjaan Indonesia Berdasarkan UndangUndang No. 13 Tahun 2003, Bandung, PT Citra Aditya Bakti.

Abdussalam dan Adri Desasfuryanto, 2015, Hukum Ketenagakerjaan (Hukum Perburuhan), Jakarta, PTIK

Asri Wijayanti, 2014, Hukum Ketenagakerjaan Pasca Reformasi, Jakarta, Sinar Grafika

Aloysius Uwiyono, dkk, 2014, Asas-Asas hukum Perburuhan, Jakarta, Rajawali Pers

H. Salim HS dan Erlies Septiana Nurbani, 2013, Penerapan Teori Hukum pada Penelitian tesis dan disertasi, Jakarta, PT. RajaGrafindo

Imam Soepomo, 2003, Pengantar Hukum Perburuhan, Jakarta, Djambatan 
Fx. Djumialdji, 1992, Pemutusan Hubungan Kerja (Perselisihan Perburuhan Perorangan), Jakarta, Rineka Cipta

Fx. Djumialdji, 2005, Perjanjian Kerja , Edisi Revisi, Jakarta, Sinar Grafika.

Sendjun H. Manulang, 1987, Pokok-Pokok Hukum Indonesia, Jakarta, Rineka Cipta.

Y.W. Sunindhia, dan Ninik Widiyanti, 1987, Masalah PHK dan Pemogokan, Jakarta, Bina Aksara

Oktavia Milayani, Kedudukan Hukum Ahli Waris Yang Mewaris Dengan Cara Mengganti Atau Ahli waris"Bij Plaaatsvervulling” Menurut Burgelijk Wetboek dalam Jurnal Al Adl, Volume IX Nomor 3, Desember 2017 